\title{
5'-Serial Analysis of Gene Expression studies reveal a transcriptomic switch during fruiting body development in Coprinopsis cinerea
}

Chi Keung Cheng ${ }^{1}$, Chun Hang Au', Sarah K Wilke², Jason E Stajich ${ }^{3}$, Miriam E Zolan ${ }^{4}$ Patricia J Pukkila² and Hoi Shan Kwan ${ }^{1 *}$

\begin{abstract}
Background: The transition from the vegetative mycelium to the primordium during fruiting body development is the most complex and critical developmental event in the life cycle of many basidiomycete fungi. Understanding the molecular mechanisms underlying this process has long been a goal of research on basidiomycetes. Large scale assessment of the expressed transcriptomes of these developmental stages will facilitate the generation of a more comprehensive picture of the mushroom fruiting process. In this study, we coupled 5'-Serial Analysis of Gene Expression (5'-SAGE) to high-throughput pyrosequencing from 454 Life Sciences to analyze the transcriptomes and identify up-regulated genes among vegetative mycelium (Myc) and stage 1 primordium (S1-Pri) of Coprinopsis cinerea during fruiting body development.
\end{abstract}

Results: We evaluated the expression of $>3,000$ genes in the two respective growth stages and discovered that almost one-third of these genes were preferentially expressed in either stage. This identified a significant turnover of the transcriptome during the course of fruiting body development. Additionally, we annotated more than 79,000 transcription start sites (TSSs) based on the transcriptomes of the mycelium and stage 1 primoridum stages. Patterns of enrichment based on gene annotations from the GO and KEGG databases indicated that various structural and functional protein families were uniquely employed in either stage and that during primordial growth, cellular metabolism is highly up-regulated. Various signaling pathways such as the CAMP-PKA, MAPK and TOR pathways were also identified as up-regulated, consistent with the model that sensing of nutrient levels and the environment are important in this developmental transition. More than 100 up-regulated genes were also found to be unique to mushroom forming basidiomycetes, highlighting the novelty of fruiting body development in the fungal kingdom.

Conclusions: We implicated a wealth of new candidate genes important to early stages of mushroom fruiting development, though their precise molecular functions and biological roles are not yet fully known. This study serves to advance our understanding of the molecular mechanisms of fruiting body development in the model mushroom C. cinerea.

Keywords: Coprinopsis cinerea, SAGE, Transcriptome, Microarray, Transcription start site, Fruiting body, Mycelium, Primordium

\footnotetext{
* Correspondence: hskwan@eservices.cuhk.edu.hk

${ }^{1}$ Food Research Centre and Food and Nutrition Sciences Programme, School of Life Sciences, Faculty of Science, The Chinese University of Hong Kong, Shatin, S.A.R., Hong Kong

Full list of author information is available at the end of the article
} 


\section{Background}

The mystery of mushroom formation has fostered a deep curiosity for understanding the molecular mechanisms underlying fruiting body initiation and development in basidiomycetes and a goal of mycological research community. Coprinopsis cinerea (previously known as Coprinus cinereus), the inky cap, is a model mushroom commonly employed to study developmental processes in agaricomycetous fungi [1]. In addition to studies related to mating types, enzyme production, and genome manipulation, much emphasis has been put on the fruiting process, particularly on the later stages including synchronous karyogamy and meiosis. This process is the most complex, yet rapid, of the developmental events in the life cycle of $C$. cinereus. When nutrients are depleted, the relatively loose mesh of undifferentiated mycelium undergoes a drastic change to form a compact multihyphal structure with many different cell types holding each other through hyphalhyphal interactions, known as the fruiting body [2]. The fruiting process can be divided into six main developmental stages: hyphal knot, initial, stage 1 primordium, stage 2 primordium, immature fruiting body and mature fruiting body [1]. Besides nutritional constraints, the normal daynight rhythm cycle is also critical for the transition of one stage to another $[3,4]$. Under ideal conditions, the whole process takes only a few days following the first sign of fruiting [5].

The advancement from mycelium (Myc) into stage 1 primordium (S1-Pri) is hypothesized to show the most significant transcriptomic changes as it represents development from an undifferentiated structure to a wellorganized multihyphal structure at a later stage of fruiting body formation. A number of genes have been previously characterized to be involved during this transition. These include the oligosaccharide-binding galectins $c g l 1$ and $c g l 2$ for potential but yet unproven mediation of hyphal interactions [6,7]; a homolog to the bacterial cyclopropane fatty acid synthase for generating stress signals as a result of membrane alteration [8]; blue light photoreceptors dst1 and $d s t 2$ for photomorphogenesis [3,4]; a Ustilago maydis adaptor protein Ubc2 homolog for filamentous growth, pheromone response and virulence [9] and a number of metabolic enzymes such as adenylate cyclase, phenol oxidase and glycogen phosphorylase [1]. Nevertheless, the lack of large scale assessment of gene expression hinders the generation of a more comprehensive picture of the fruiting process. In order to better understand the molecular basis underlying this transition, it is desirable to identify the genes differentially expressed among these two developmental stages through comparing the respective transcriptomes. Such studies are especially feasible in $C$. cinerea because of the recent release of its $37.5 \mathrm{Mb}$ genomic sequence and predicted gene set consisting of 13,342 protein-coding genes [10].
Serial Analysis of Gene Expression (SAGE), invented in 1995, is a digital expression tag profiling technology for high throughput genomic-level evaluation of transcriptomes [11]. Over the past 17 years, SAGE has become a wellrecognized tool and has been extensively used in human, animal, yeast, plant and fungal studies [12]. The advancement of next-generation DNA sequencing technologies in recent years has enabled SAGE analysis to attain higher throughput, sensitivity and cost-effectiveness compared to the original cloning-based and Sanger sequencing approaches [13-15]. In addition, the SAGE protocol was improved based on a combination of $5^{\prime}$ RACE and SAGE, known as 5'-SAGE, which extracts the first $15-17$ bp of each mRNA transcript $[16,17]$. This allows simultaneous characterization of the transcriptome and transcription start site (TSS). The TSS data are invaluable for identification and analyses of promoter regions and cis-regulatory elements that contribute to better understanding of higher-order regulatory mechanisms [18]. The $>100$ bp sequence reads available with 454 Life Sciences (GS20) sequence technology [19] is well-suited for the length of 5'-SAGE ditags. The short length, but more numerous sequences from the 454 approach allows the tedious steps of concatenation and colony picking in the original SAGE procedures to be bypassed.

Here, we report a high throughput analysis of the two 5'-SAGE libraries, supplemented by oligomicroarray data, for comprehensive assessment of the transcriptomes of $C$. cinereus at the Myc and S1-Pri stages. A wealth of novel candidate genes and molecular mechanisms related to fruiting body initiation and development are identified from the comparison of the gene expression profiles at these stages. The genes and pathways identified will serve as an important platform for future studies in developmental biology of basidiomycetes.

\section{Results and discussion}

\section{Sequencing of 5'-SAGE ditags and separation into tags}

The 5'-SAGE libraries were constructed from each Myc and S1-Pri mRNA preparations and we obtained a total of 198,809 valid ditags from both developmental stages. At an average read length of 95.5 bases, the sequences accounted for $94.9 \%$ of the GS20 sequencer throughput. After tag extraction and quality filtering, we obtained a total of 253,415 valid tags, with 107,046 from the Myc stage and 146,369 from the S1-Pri stage.

\section{Tag to gene assignment}

All the Myc and S1-Pri tags were assigned to the $C$. cinerea genome assembly [10] by in-house Perl scripts and no mismatches were allowed. We found approximately $80 \%$ of the 107,046 Myc tags and the 146,369 S1-Pri tags matched perfectly to the genome with no mismatches (Table 1). Such percentage is comparable to previous studies using similar 
Table 1 Summary of tag extraction and C. cinerea genome mapping

\begin{tabular}{ccc}
\hline & Myc 5'-SAGE & S1-Pri 5'-SAGE \\
\hline Total valid tags & 107046 & 146369 \\
Genome mapping & & \\
- Unique match to genome & $88053(82.3 \%)$ & $118257(80.8 \%)$ \\
- Multiple matches to genome & $7622(7.1 \%)$ & $10685(7.3 \%)$ \\
- 2-4 matches & $7065(6.6 \%)$ & $9953(6.8 \%)$ \\
- 5-10 matches & $428(0.4 \%)$ & $586(0.4 \%)$ \\
- $\geq 11$ matches & $138(0.1 \%)$ & $146(0.1 \%)$ \\
- No match to genome & $11371(10.6 \%)$ & $17427(11.9 \%)$ \\
\hline
\end{tabular}

techniques $[16,17,20]$. Meanwhile, an average of $7.2 \%$ of tags matched to multiple positions and $11.3 \%$ could not be mapped to the genome (Table 1). Most of the multiple mapping tags ( $>90 \%)$ were perfectly aligned to $2-4$ genomic positions of non-homologous genes but were discarded from further analysis due to the impossibility of confidently assigning them to unique genome positions. The tags which failed to match the genome were likely the result of unique sequence in the strain sequence discrepancies between the reference monokaryotic strain (Okayama-7 \#130) and the dikaryon used in this study. In addition, as suggested by Keime et al. [21], a smaller proportion could result from tags spanning splice junction of two exons. The tags mapped to the $C$. cinerea genome and predicted gene models can be retrieved in the link http://kwanlab.bio.cuhk. edu.hk/cgi-bin/gb2/gbrowse/cc.

Most transcription start sites (TSSs) were located within 200 bp upstream of the translation start codon, and more than $90 \%$ of the tags with more than 2 occurrences were within 500 bp upstream of an annotated gene (data not shown). Combining these observations and those from previous reports [22-24], we adopted a length of $500 \mathrm{bp}$ for the putative $5^{\prime}$-untranslated region $\left(5^{\prime}\right.$-UTR) and 500 bp for the $3^{\prime}$-UTR. We observed that $56.5 \%$ of the Myc tags and $52.4 \%$ of S1-Pri tags mapped to the $5^{\prime}$-UTR, $15.0 \%$ and $17.1 \%$ to the annotated coding region, and 3.3\% and $2.6 \%$ to the $3^{\prime}$-UTR respectively (Table 2 ). Considering the tags mapping to the $5^{\prime}$-UTR, we annotated more than 34,000 Myc and more than 45,000 S1-Pri specific TSSs (79,000 total) of more than 3,000 genes. Most of these start sites were arranged in an array manner (Figure 1) and such arrangement agrees with the observations in many other organisms $[17,20,25,26]$. We believe the 5'-SAGE tags represent genuine transcription start sites and support the accuracy of the computer-predicted gene models. Investigation of the most highly expressed genes revealed that most have more than one TSS with one or two more preferred TSSs (Figure 1). Intriguingly, noticeable proportions (14.3\% in Myc and 17.4\% in S1-Pri) of tags were mapped in antisense direction to annotated
Table 2 Gene-associated positions of tags mapped to the C. cinerea genome

\begin{tabular}{lcc}
\hline & Myc 5'-SAGE $^{\prime}$ & S1-Pri 5'-SAGE \\
\hline Putative 5'-UTR (-500, -1) $^{\text {a }}$ & $49718(56.5 \%)$ & $61964(52.4 \%)$ \\
Putative 5'-UTR (Anti-sense) $^{\mathrm{b}}$ & $4363(5.0 \%)$ & $8826(7.5 \%)$ \\
Coding region (sense) $^{\text {Coding region (Anti-sense) }}{ }^{\mathrm{b}}$ & $13201(15.0 \%)$ & $20195(17.1 \%)$ \\
Putative 3'-UTR (+1, +500) $^{\mathrm{a}}$ & $6030(6.8 \%)$ & $8902(7.5 \%)$ \\
Putative 3'-UTR (Anti-sense) $^{\mathrm{b}}$ & $2867(3.3 \%)$ & $3031(2.6 \%)$ \\
Unclassified $^{\mathrm{c}}$ & $2231(2.5 \%)$ & $2889(2.4 \%)$ \\
Total & $9643(10.9 \%)$ & $12450(10.5 \%)$ \\
\hline
\end{tabular}

${ }^{a}$ The $(-500,-1)$ refers to position upstream of the annotated ATG start codon, while $(+1,+500)$ refers to position downstream of the STOP codon.

b 'Anti-sense' means that the tag is in opposite orientation of the putative 5 '/ $3^{\prime}$-UTR, or annotated coding region.

c 'Unclassified' means that the tags could not be assigned to any annotated gene.

genes, especially to the $5^{\prime}$-UTR and coding region (Table 2 ). Some of these tags could be identified in both the Myc and S1-Pri libraries, implying that they did not occur spuriously (Figure 2). We speculate that they may represent TSS of non-coding RNAs (ncRNAs) with regulatory functions that control gene expression [27-29]. However, further analysis of these non-coding RNAs is beyond the scope of the present study.

\section{Profiling and functional annotation of the differentially expressed genes (DEGs)}

To evaluate the expression level of genes, we only considered the tags mapping to the $5^{\prime}$-UTR regions of individual genes. We evaluated the expression level of a total of 3,270 genes (Additional file 1), of which 1,911 and 2,732 were expressed in Myc and S1-Pri stages respectively (Table 3). This represented approximately one-fourth of the 13,342 predicted protein-coding genes (Broad Institute, assembly version 3) [30] in the C. cinerea genome. Gene expression of these genes was tested with a Fisher's Exact Test comparing observed tag counts out of the entire and an unadjusted $p$-value of 0.05 . 324 genes were found to be preferentially expressed in Myc (Table 4, Additional file 2) while 716 genes were up-regulated in S1-Pri (Table 5, Additional file 3). This indicates that almost one-third of the assessed genes were up-regulated in either stage, implying a significant turnover of the transcriptome during the transition from mycelium to primordium. Most of the DEGs had shown more than 3-fold up-regulation in either Myc (91\%) or S1-Pri (75\%) stages (Table 3).

The DEGs were characterized by annotation using the Gene Ontology (GO) database [31]. GO terms were assigned to the DEGs (see "Methods"). A higher proportion of DEGs in the S1-Pri stage could be assigned at least one GO term, with 530 (out of 716, 74\%) compared to 146 (out of 324, 45\%) as in the Myc stage (Table 3). 


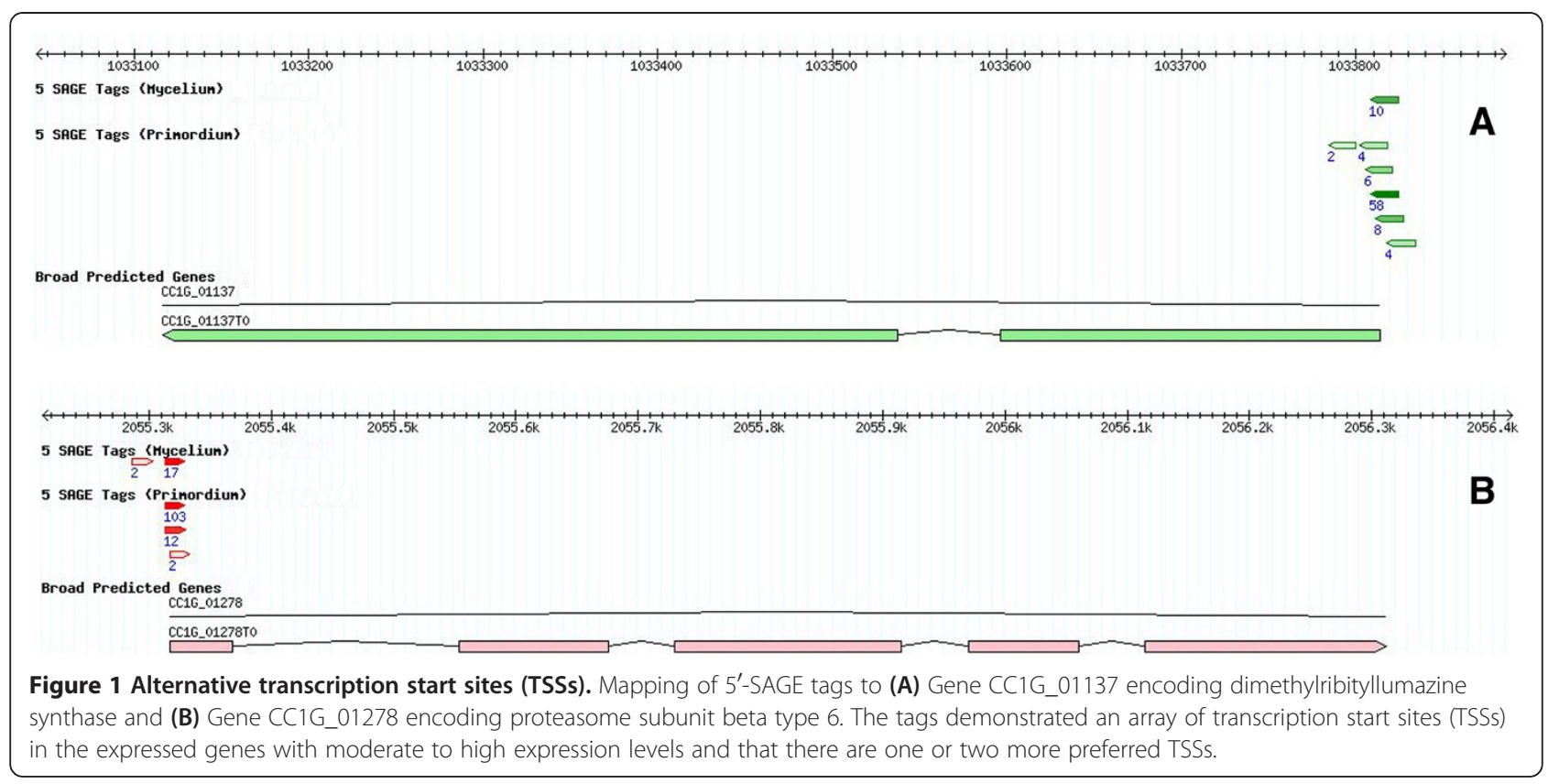

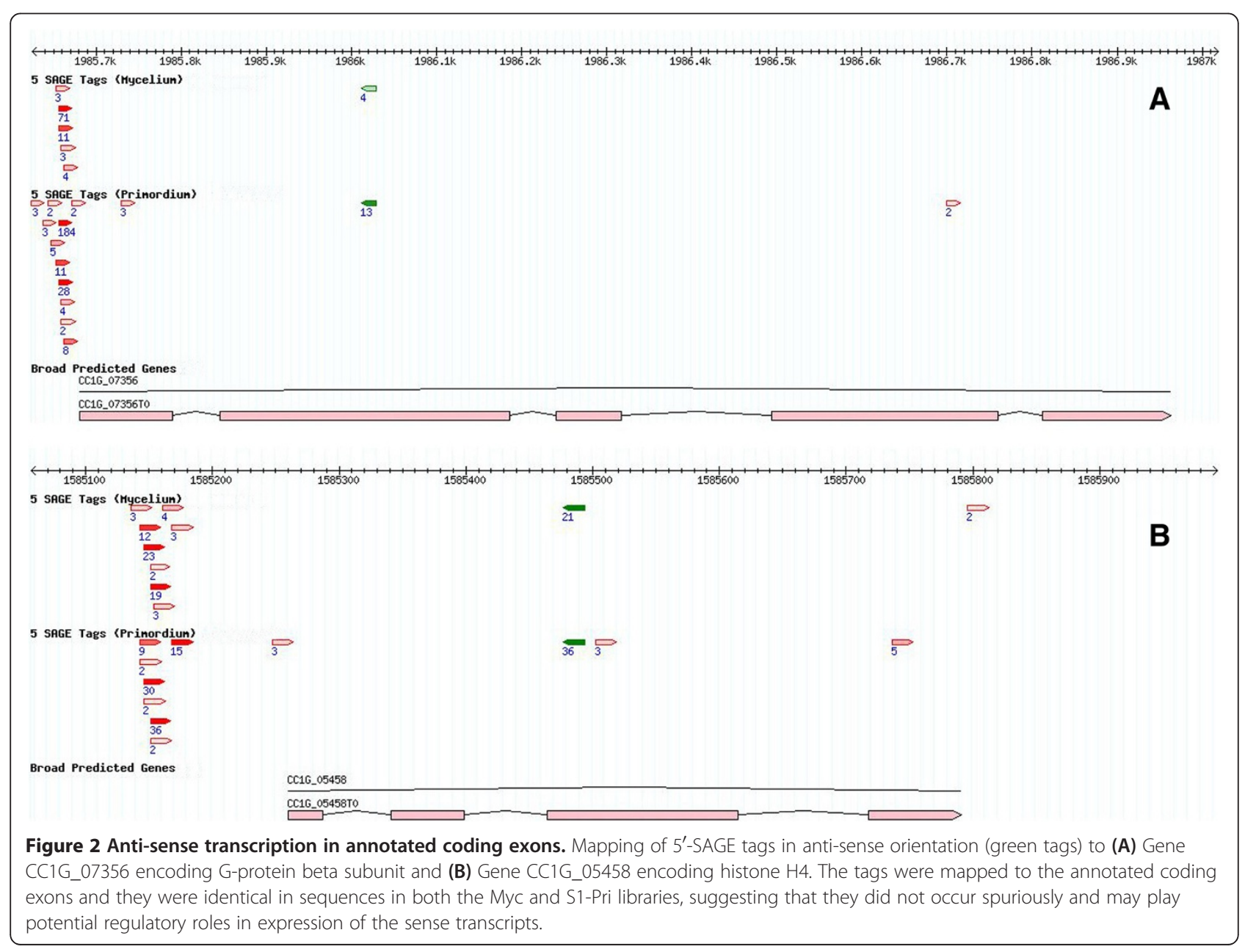


Table 3 Statistics of the Myc and S1-Pri differentially expressed genes (DEGs)

\begin{tabular}{|c|c|c|}
\hline & Myc 5'-SAGE & S1-Pri 5'-SAGE \\
\hline No. of genes with detected expression & 1911 & 2732 \\
\hline No. of differentially expressed genes (DEGs) & $324(17.0 \%)$ & $716(26.2 \%)$ \\
\hline \multicolumn{3}{|l|}{ No of DEGs } \\
\hline with homolog identified in BLASTX ${ }^{b}$ & $157(48.5 \%)$ & $500(69.8 \%)$ \\
\hline with $>3$-fold up-regulation & $295(91.0 \%)$ & $538(75.1 \%)$ \\
\hline with GO term & $146(45.1 \%)$ & $530(74.0 \%)$ \\
\hline with KEGG ortholog & $56(17.3 \%)$ & $270(37.7 \%)$ \\
\hline unique to fruiting body-forming & $22(6.8 \%)$ & $30(4.2 \%)$ \\
\hline \multicolumn{3}{|l|}{ basidiomycetes $^{c}$} \\
\hline unique to $C$. cinerea & $41(12.7 \%)$ & $22(3.1 \%)$ \\
\hline No. of enriched protein domains ${ }^{d}$ & 118 & 115 \\
\hline
\end{tabular}

We have also mapped all the DEGs to the Kyoto Encyclopedia of Genes and Genomes (KEGG) pathways database to investigate molecular interactions and reaction networks [32]. Consistent with our expectations, an overall up-regulation of various cellular processes between the undifferentiated mycelium and the primordium stage 2 days prior to karyogamy was observed. Analysis result from the GO and KEGG is available in the supplemental files 5, 6, 7 and subsections "More DEGs in S1-Pri were assigned a GO term in Gene Ontology analysis" and "KEGG pathways analysis revealed an increased cellular metabolism in S1-Pri" respectively.

\section{Validations of $5^{\prime}$-SAGE with microarray gene expression and real-time RT-PCR}

Genome-wide 70-mer oligonucleotide microarray [10,33] experiments were also performed for all predicted genes using similar RNA samples as in the $5^{\prime}$-SAGE experiments.

Table 4 List of top 15 differentially expressed genes in the Myc stage

\begin{tabular}{|c|c|c|c|c|c|c|c|c|}
\hline Gene ID & $\mathrm{Myc}^{\mathrm{a}}$ & S1-Pri ${ }^{\mathrm{a}}$ & $\begin{array}{l}\log _{2} \\
\text { ratiob }\end{array}$ & BLASTX homolog [Organism] & Accession ID & e-value & KO term ${ }^{c}$ & GO term ${ }^{d}$ \\
\hline CC1G_02184T0 & 879.2 & 0.0 & 9.78 & CoH1 [Coprinopsis cinerea] & CAA71652 & $2.85 E-30$ & $\mathrm{~N} / \mathrm{A}$ & $\mathrm{N} / \mathrm{A}$ \\
\hline CC1G_07511T0 & 752.1 & 0.0 & 9.55 & $\begin{array}{l}\text { hemerythrin HHE cation binding domain } \\
\text { protein [Neosartorya fischeri NRRL 181] }\end{array}$ & XP_001261781 & $3.71 \mathrm{E}-13$ & $\mathrm{~N} / \mathrm{A}$ & $N / A$ \\
\hline CC1G_08199T0 & 516.0 & 0.0 & 9.01 & & & & $\mathrm{~N} / \mathrm{A}$ & $\mathrm{N} / \mathrm{A}$ \\
\hline CC1G_08735T0 & 482.7 & 0.0 & 8.92 & & & & $\mathrm{~N} / \mathrm{A}$ & $\mathrm{N} / \mathrm{A}$ \\
\hline CC1G_11444T0 & 460.0 & 0.0 & 8.85 & & & & N/A & GO:0005634 \\
\hline CC1G_12265T0 & 970.0 & 2.1 & 8.83 & & & & $\mathrm{~N} / \mathrm{A}$ & GO:0005811 GO:0004252 \\
\hline CC1G_02183T0 & 729.4 & 2.1 & 8.42 & CoH1 [Coprinopsis cinerea] & CAA71652 & $6.28 \mathrm{E}-29$ & $\mathrm{~N} / \mathrm{A}$ & $\mathrm{N} / \mathrm{A}$ \\
\hline CC1G_13813T0 & 293.6 & 0.0 & 8.20 & & & & $\mathrm{~N} / \mathrm{A}$ & $\mathrm{N} / \mathrm{A}$ \\
\hline CC1G_07100T0 & 272.4 & 0.0 & 8.09 & & & & $\mathrm{~N} / \mathrm{A}$ & $\mathrm{N} / \mathrm{A}$ \\
\hline CC1G_10342T0 & 254.2 & 0.0 & 7.99 & & & & $\mathrm{~N} / \mathrm{A}$ & $\mathrm{N} / \mathrm{A}$ \\
\hline CC1G_11525T0 & 236.1 & 0.0 & 7.88 & $\begin{array}{l}\text { putative phosphatidic acid phosphatase } \\
\text { [Pleurotus sp. \&apos;Florida\&apos;] }\end{array}$ & CAD10795 & $3.17 \mathrm{E}-47$ & N/A & $\begin{array}{c}\text { GO:0005887 GO:0008195 } \\
\text { GO:0006644 }\end{array}$ \\
\hline CC1G_00675T0 & 230.0 & 0.0 & 7.85 & & & & $\mathrm{~N} / \mathrm{A}$ & $\mathrm{N} / \mathrm{A}$ \\
\hline CC1G_07531T0 & 151.3 & 0.0 & 7.24 & & & & $\mathrm{~N} / \mathrm{A}$ & $\mathrm{N} / \mathrm{A}$ \\
\hline CC1G_04294T0 & 149.8 & 0.0 & 7.23 & & & & $\mathrm{~N} / \mathrm{A}$ & $\mathrm{N} / \mathrm{A}$ \\
\hline CC1G_12264T0 & 139.2 & 0.0 & 7.12 & & & & N/A & N/A \\
\hline
\end{tabular}

${ }^{a}$ Relative expression level expressed as tags per 100,000.

${ }^{\mathrm{b}} \mathrm{Log}_{2}$ of the expression ratio of Myc/S1 Pri.

c KEGG orthology term.

d Gene Ontology term. 
Table 5 List of top 15 differentially expressed genes in the S1 Pri stage

\begin{tabular}{|c|c|c|c|c|c|c|c|c|}
\hline Gene ID & $\mathrm{Myc}^{\mathrm{a}}$ & S1-Pria & $\log _{2}$ & BLASTX homolog [Organism] & Accession ID & e-value & KO term ${ }^{c}$ & GO term ${ }^{d}$ \\
\hline$\overline{C C 1 G \_05471 T 0}$ & 0.0 & 620.5 & -9.28 & & & & N/A & N/A \\
\hline CC1G_09700T0 & 0.0 & 530.8 & -9.05 & & & & N/A & N/A \\
\hline CC1G_03340T0 & 0.0 & 374.8 & -8.55 & & & & N/A & N/A \\
\hline CC1G_06766T0 & 0.0 & 244.6 & -7.93 & & & & N/A & N/A \\
\hline CC1G_04060T0 & 0.0 & 197.6 & -7.63 & & & & N/A & N/A \\
\hline CC1G_06484T0 & 0.0 & 147.4 & -7.20 & hydrophobin [Tricholoma terreum] & AAL05426 & 9.96E-06 & N/A & N/A \\
\hline CC1G_11781T0 & 0.0 & 141.0 & -7.14 & & & & N/A & N/A \\
\hline CC1G_04061T0 & 0.0 & 104.7 & -6.71 & hydrophobin [Tricholoma terreum] & AAL05426 & $9.21 \mathrm{E}-07$ & N/A & N/A \\
\hline CC1G_01315T0 & 0.0 & 99.3 & -6.63 & endochitinase [Amanita muscaria] & CAC35202 & $2.59 \mathrm{E}-85$ & N/A & GO:0004568 GO:0006032 \\
\hline CC1G_12474T0 & 0.0 & 83.3 & -6.38 & xyn11C [Chaetomium thermophilum] & CAD48751 & 4.69E-68 & N/A & $\begin{array}{c}\text { GO:0005576 GO:0016798 } \\
\text { GO:0045493 }\end{array}$ \\
\hline CC1G_03570T0 & 4.5 & 314.0 & -6.11 & & & & N/A & N/A \\
\hline CC1G_14841T0 & 0.0 & 66.2 & -6.05 & & & & N/A & GO:0051015 \\
\hline CC1G_01233T0 & 0.0 & 60.9 & -5.93 & $\begin{array}{l}\text { membrane transporter [Cryptococcus } \\
\text { neoformans var. neoformans JEC21] }\end{array}$ & XP_567607 & 9.43E-37 & N/A & N/A \\
\hline CC1G_10308T0 & 0.0 & 57.7 & -5.85 & & & & N/A & N/A \\
\hline CC1G_14100T0 & 0.0 & 56.6 & -5.82 & $\begin{array}{l}\text { histidine acid phosphatase, putative } \\
\text { [Aspergillus clavatus NRRL 1] }\end{array}$ & XP_001276358 & $2.98 \mathrm{E}-06$ & N/A & N/A \\
\hline
\end{tabular}

Relative expression level expressed as tags per 100,000.

${ }^{b} \log _{2}$ of the expression ratio of Myc/S1 Pri.

c KEGG orthology term.

${ }^{\mathrm{d}}$ Gene Ontology term.

The microarray data successfully evaluated expression levels of 8,667 predicted genes (Additional file 4), of which 520 were found to have a false discovery rate $<1 \%$ using SAM with a 2-fold up-regulation in Myc while 518 were up-regulated in S1-Pri under the same criteria. We randomly selected 18 genes, which covered a spectrum of expression ratios between Myc and S1-Pri genes, for realtime RT-PCR to validate the reliability of the $5^{\prime}$-SAGE dataset (Table 6). We found a significant correlation between the real-time PCR results and the 5'-SAGE data $(\mathrm{R}=0.936)$, suggesting that the $5^{\prime}$-SAGE data can reliably measure the expression levels of individual genes. The correlation of the oligonucleotide microarray to $5^{\prime}$-SAGE results was also high $(\mathrm{R}=0.792)$ for the same set of 18 genes. Thus, both the real-time PCR and microarray data confirmed the expression profiles of the $5^{\prime}$-SAGE dataset. However, 562 genes assessed in $5^{\prime}$-SAGE were not detected in the microarray data perhaps due to differential sensitivity of sequencing versus hybridization chemistry.

\section{Gene expression differences among gene families}

Among the 324 up-regulated genes in the mycelium stage, only 157 (49\%) have a homolog identified through BLASTX search in the NCBI GenBank $\left(\mathrm{e}<10^{-5}\right)$ (Table 3). Compared to $70 \%$ (500 out of 716 DEGs) as in the S1-Pri stage, this highlighted that many of the mycelial genes are actually novel. Expression of the hydrophobin 1 gene (coh1,
CC1G_02183), 3 hydrophobin genes that are in tandem with coh1 (CC1G_02181, CC1G_02182, CC1G_02184) and 2 other hydrophobin genes (CC1G_04843, CC1G_10189) in Myc revealed that two abundantly expressed ones (CC1G_02183, CC1G_02184) are among the 10 most highly expressed in this stage. All 6 genes show significantly reduced expression in S1-Pri including 4 with no detectable expression. Inverse expression patterns were seen in 4 hydrophobin genes (CC1G_01230, 06484, 04060, 04061), which were highly expressed in S1-Pri but had no detectable transcripts in Myc in 5'-SAGE. The expression of the hydrophobin 2 gene (coh2, CC1G_02185) was not detected in either developmental stage. These observations are consistent with previous findings in the mushrooms Lentinula edodes and Pleurotus ostreatus which employ two different sets of hydrophobin genes during fruiting body development $[34,35]$. These hydrophobins are thought to play alternative structural roles in the respective stages.

A similar phenomenon is observed for the heat shock proteins (HSP). We found 5 HSPs up-regulated in Myc (CC1G_01131, CC1G_02271, CC1G_02341, CC1G_ 04585, CC1G_15006), whereas 2 are up-regulated in S1-Pri together with 1 heat shock transcription factor (CC1G_04586, CC1G_13982, CC1G_10208). We speculate that the widely employed mycelial cultivation temperature of $37^{\circ} \mathrm{C}$ compared to the standard fruiting temperature of $25^{\circ} \mathrm{C}[8,10,33]$ may be partly responsible for this, while 
Table 6 Correlation of expression of 18 randomly-selected genes among 5'-SAGE, microarray and real-time RT-PCR

\begin{tabular}{|c|c|c|c|c|}
\hline & Description & $5^{\prime}-\mathrm{SAGE}^{\mathrm{a}}$ & Microarray $^{a}$ & Real-time RT-PCR \\
\hline CC1G_04976 & Thiazole biosynthetic enzyme & 6.48 & 3.34 & 3.80 \\
\hline CC1G_03790 & Glutamate decarboxylase & 5.55 & 1.64 & 3.55 \\
\hline CC1G_00577 & CMGC/MAPK protein kinase & 4.41 & 1.41 & 2.76 \\
\hline CC1G_03377 & Protoporphyrinogen oxidase & 3.41 & -0.17 & 1.66 \\
\hline CC1G_00689 & Thioredoxin & 3.16 & 0.72 & 2.91 \\
\hline CC1G_07379 & Hypothetical protein & 1.57 & 0.19 & 1.59 \\
\hline CC1G_06934 & Hypothetical protein & 1.06 & -0.85 & 1.34 \\
\hline CC1G_02958 & Actin cytoskeleton protein VIP1 & 0.82 & 0.79 & 0.92 \\
\hline CC1G_10110 & Ubiquitin-carboxy protein fusion & -0.05 & -0.35 & -0.32 \\
\hline CC1G_03278 & ATP synthase subunit 5 & -0.07 & -0.21 & -0.41 \\
\hline CC1G_07540 & 605 ribosomal protein $L 34-b$ & -0.16 & -0.64 & -0.45 \\
\hline CC1G_07277 & 40 S ribosomal protein S14 & -0.95 & -0.41 & -0.78 \\
\hline CC1G_01940 & ATP-synthase delta-subunit & -1.34 & -0.73 & -1.23 \\
\hline CC1G_03707 & Prohibitin & -1.43 & -0.37 & -1.44 \\
\hline CC1G_09336 & Basic leucine zipper \& W2 domain-containing protein 2 & -1.97 & -1.17 & -1.98 \\
\hline CC1G_06761 & Glycine dehydrogenase & -4.42 & 0.45 & -0.82 \\
\hline CC1G_14100 & Hypothetical protein & -5.82 & -1.53 & -3.42 \\
\hline CC1G_01315 & Endochitinase & -6.63 & -1.45 & -4.66 \\
\hline \multicolumn{5}{|c|}{ Correlation of $5^{\prime}$-SAGE and real-time PCR: $R=0.936$} \\
\hline & \multicolumn{4}{|c|}{ Correlation of $5^{\prime}$-SAGE and microarray: $\mathrm{R}=0.792$} \\
\hline
\end{tabular}

${ }^{a}$ Values expressed as $\log _{2}$ ratio of Myc/S1-Pri.

other stresses during fruiting development may turn on the corresponding HSPs in the S1-Pri stage [36]. Notably, among the 30 most highly expressed DEGs in Myc, only 7 of them have a detectable homolog in BLASTX search $\left(\mathrm{e}<10^{-5}\right)$. Apart from two of the aforementioned hydrophobin genes, 3 of them (CC1G_07702, CC1G_08572, CC1G_08573) correspond to "mismatched base pair and cruciform DNA recognition protein" which is highly conserved among the fungal kingdom (A. bisporus homolog, NCBI accession ID: CAB85690). Little is known of their molecular functions and biological roles in fungal development, but the observations that this family of proteins were among the 5 most highly expressed in Myc and were significantly repressed in S1-Pri highlight their potential involvement in fruiting body development.

\section{Genes up-regulated in stage 1 primordium}

Despite a larger number of genes in the S1-Pri stage for which a homolog can be identified, excluding the mating type genes [37], few other genes have been described as playing a role in fruiting body formation in C. cinerea. Some developmentally regulated genes previously characterized include the galectins ( $\beta$-galactoside binding lectins, CGLs). We showed that the expression of cgl1 (CC1G_05003), which is highly up-regulated in S1-Pri, is in agreement with a previous report [38]. However, the expression of $\mathrm{cgl} 2$ was not detected in either Myc or S1-Pri stage in our study. One potential explanation for this, as suggested by Boulianne et al. [39], is that cgl2 expression may be repressed by sufficient nutrient levels in the medium (as for Myc) or under light illumination (as for S1-Pri) which resemble the conditions under which our RNA samples were harvested. Our data also revealed the expression of a $\mathrm{cgl3}$ gene with novel carbohydrate-binding specificities (CC1G_00723) [40], which is highly up-regulated in S1-Pri as well. Cgl3 is dissimilar in protein sequence to both Cgl1 and Cgl2. The most related homolog is a galectin gene from the ectomycorrhizal basidiomycete Laccaria bicolor (NCBI accession ID: XP_001877242), yet the homologs are only $58 \%$ identical with no other significantly similar sequences identified. The uniqueness and differential expression of cgl3 probably deserves a deeper investigation.

The expression of tubulin genes has been previously explored [41-43]. Examination of this gene family found three components of microtubules: alpha1 tubulin (CC1G_ 01375), alpha2 tubulin (CC1G_00146), beta tubulin (CC1G_04743), which are all up-regulated in S1-Pri with a similar 5 -fold of change, accompanied by a 3-fold increase of a tubulin-specific chaperone (CC1G_00477) suggesting that microtubule formation is systematically regulated and necessary for early fruiting events. 


\section{More DEGs in S1-Pri were assigned a GO term in Gene Ontology analysis}

We inferred the gene characteristics of the Myc and S1-Pri DEGs using the Gene Ontology (GO) [31] database. A total of 146 Myc DEGs were assigned to GO terms consisting of 92 cellular components, 111 molecular functions and 99 biological processes, while 530 S1-Pri DEGs were assigned to 423 cellular components, 411 molecular functions and 409 biological processes respectively (Additional file 5, we recommend viewing using Gene Ontology Browsing Utility [44]). We specifically focused on those assigned to the category "Molecular function" and "Biological Process" for further investigation. More DEGs in the S1-Pri stage than Myc can be assigned a role in molecular function (34\% in Myc against $56 \%$ in S1-Pri) and biological process (31\% in Myc against $57 \%$ in S1-Pri), again highlighting the phenomenon that many mycelial genes are novel. We observed a large number of S1-Pri DEGs being assigned to molecular functions including transcription factor binding, DNA/RNA binding, GTPase regulator activity, transcriptional activator/repressor activity and ion transport activity
(Figure 3). Concerning gene expression, we identified transcription regulators (5 in Myc; 42 in S1-Pri), which implies that genes are under different transcriptional regulation during fruiting body formation.

The biological processes observed among the DEGs could play important roles during fruiting body formation including cell adhesion, signal transduction, sensing of extracellular stimuli, responding to stress and in the regulation of cellular process (Figure 4). Notably, in addition to the components of the cAMP and MAP kinase signaling pathways to be discussed below, we uncovered 31 DEGs involved in other signal transduction processes (6 in Myc; 20 in S1-Pri) and regulation of signal transduction (1 in Myc; 4 in S1-Pri) through GO analysis. This suggests different signaling cascades may be required to transduce various signals into either mycelial growth or fruiting body development $[45,46]$. Many of the Myc DEGs cannot be assigned to any GO term, but despite this a similar number of genes were assigned to "response to abiotic stimulus" and "response to nutrient levels" when compared to the S1-Pri DEGs, suggesting that $C$. cinerea may employ a different

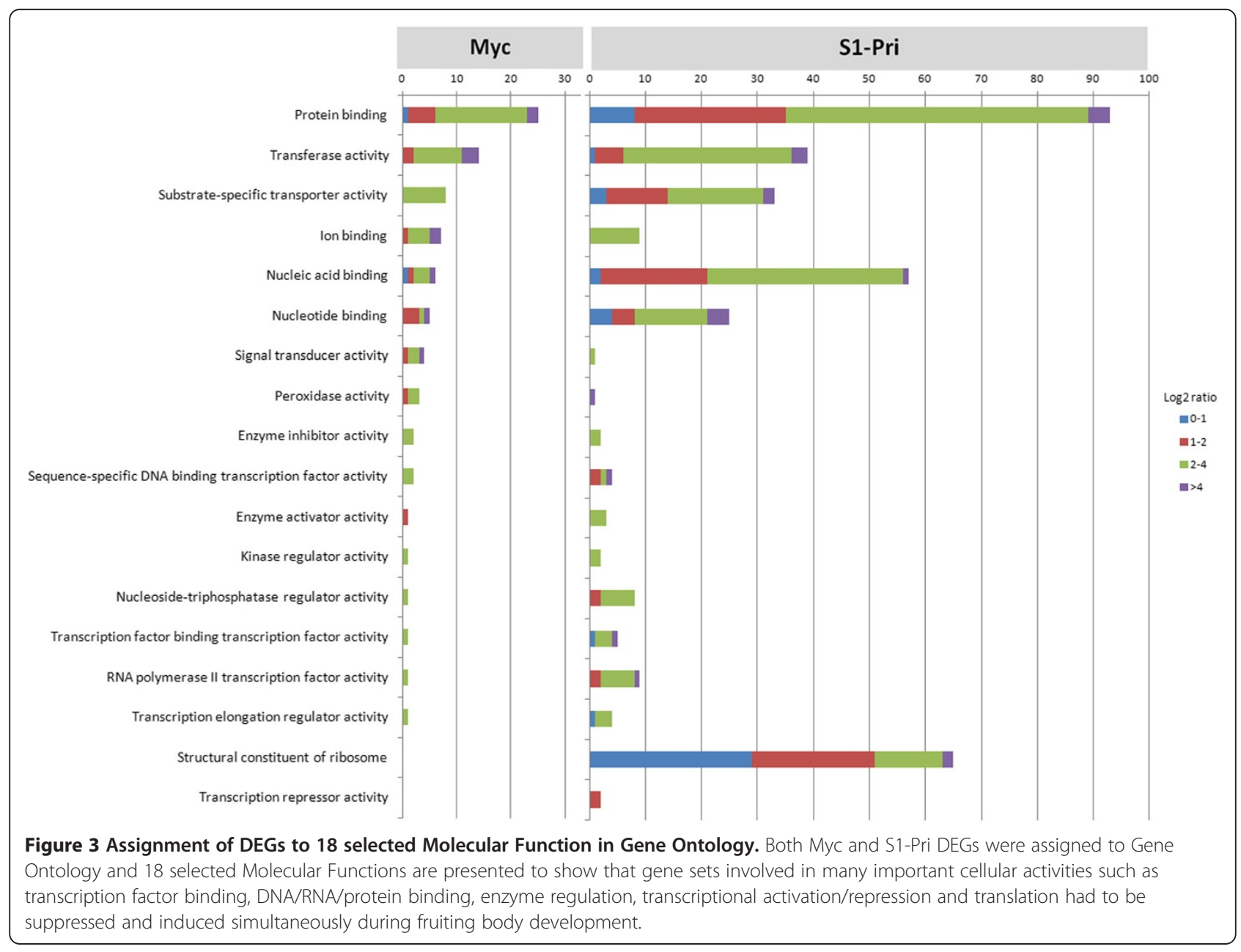




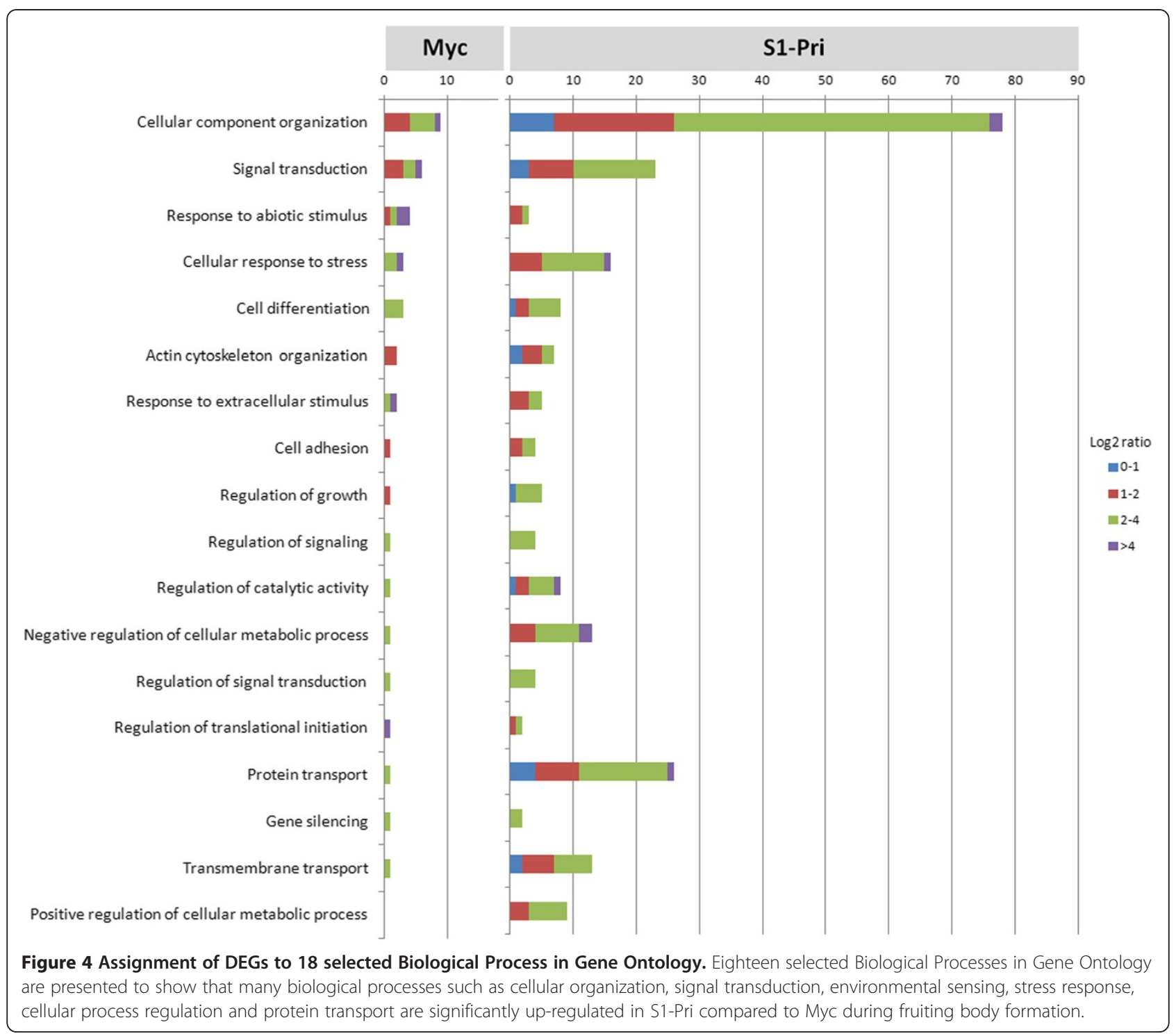

set of genes to sense the environment and to transduce the corresponding signals to development. Two of the terms are even unique to the Myc stage, which include "a specific receptor and receptor signaling protein functions" and "certain antioxidant activities".

\section{Involvement of nutrient-related pathways in fruiting body} development

In addition to the 2 aforementioned genes encoding galectins $c g l 1$ and $c g l 3$, which were assigned directly to the category 'sporocarp (fruiting body) development' [39,40], 2 Myc and 4 S1-Pri genes were predicted to play a role in response to nutrient levels, as nutrient depletion is believed to be one of the primary factors for fruiting $[2,8]$. Three of these genes (CC1G_00577, CC1G_00269 and CC1G_ 11556) are highly conserved in animals and fungi but not in plants, and the remaining three (CC1G_03709, CC1G_04470 and CC1G_12113) are highly conserved in fungi. These six proteins consist of one protein kinase, one rheb GTPase, one endopeptidase and three hypothetical proteins. Nevertheless, they are not assigned to any known nutrient-related pathways including the cAMP and MAP kinase pathways discussed below. Meanwhile, we specifically investigated the cAMP signaling pathway, which functions in parallel with the MAPK cascade. This pathway involves a novel $G$ protein-coupled receptor, $G$ protein alpha, adenylyl cyclase, cyclic AMP (cAMP), cAMP-dependent protein kinase and Ras [45]. The homo$\log$ of Cryptococcus neoformans $\mathrm{G} \alpha$ protein $\mathrm{Gpa} 1$ and $U$. maydis Gpa3, a conserved subgroup of fungal "cAMP-type" $\mathrm{G} \alpha$ proteins, has been implicated to respond primarily to nutrient deprivation signals by inducing cAMP levels 
and subsequently activating cAMP-dependent protein kinase (PKA) [47]. Physiological studies revealed that "cAMP-type" Ga protein homolog and adenylyl cyclase controlled cAMP production in response to glucose, and that intracellular cAMP levels rises in $C$. cinerea during hyphal knot and primordium formation as a result of $\mathrm{G \alpha}$ protein activation [45,48]. Since our $5^{\prime}$-SAGE showed reduced expression for many of the components in the cAMP pathway, we employed real-time PCR to verify their expression levels. We demonstrated that the expression of both the C. cinerea gpa1 homolog (CC1G_09275) and the adenylyl cyclase gene (CC1G_02340) remain approximately unchanged between the Myc and the S1-Pri stage. However, a 1.9-fold up-regulation of the cAMP-dependent protein kinase (PKA) regulatory subunit (yeast Bcyl homolog, CC1G_00440) [49] was recorded, and expression of two genes encoding the cAMP-dependent protein kinase catalytic subunit (CC1G_05183 \& 04466) was reduced by half. This is somewhat contradictory to the observation by Swamy et al. [50], as they reported that adenylyl cyclase level was decreasing in mated dikaryon after it peaked at 6 days post-incubation. It is to be noted that they did not compare PKA activity between the mycelium and the primordium stages. However, in line with the observation by Yamagishi et al. [51], expression of PKA was also greatly reduced in mushroom-forming Schizophyllum commune dikaryons. This intriguing observation of an apparently down-regulation of the known downstream targets of a $\mathrm{G \alpha}$ protein-mediated signaling pathway argues against the role of PKA as a downstream effector controlling mushroom formation. We hypothesize that the down-regulation of PKA may be responsible during fruiting body formation for the suppression of its targets, likely a variety of transcription factors, and that the observed increase in cAMP levels may serve roles other than activating PKA as in $C$. neoformans and $U$. maydis (Figure 5).

\section{Involvement of the MAP kinase pathway in fruiting body development}

As far as the cAMP-PKA signaling pathway is concerned, we are also interested in investigating the MAP kinase (MAPK) signaling pathway, since it has been welldocumented that the two pathways function in parallel with cross talk between them $[46,52,53]$. In $U$. maydis, the MAP kinase homolog Ubc3 is essential for pheromone responses, mating and filamentation [54], and similar developmental roles have also been described in budding yeast [55], $C$. neoformans [56] and Neurospora crassa [57]. However, the role of the MAPK cascade in fruiting body development in basidiomycetes has not been studied in great detail save for observations such as MAPK was found preferentially expressed in primordium and young fruiting bodies in $L$.

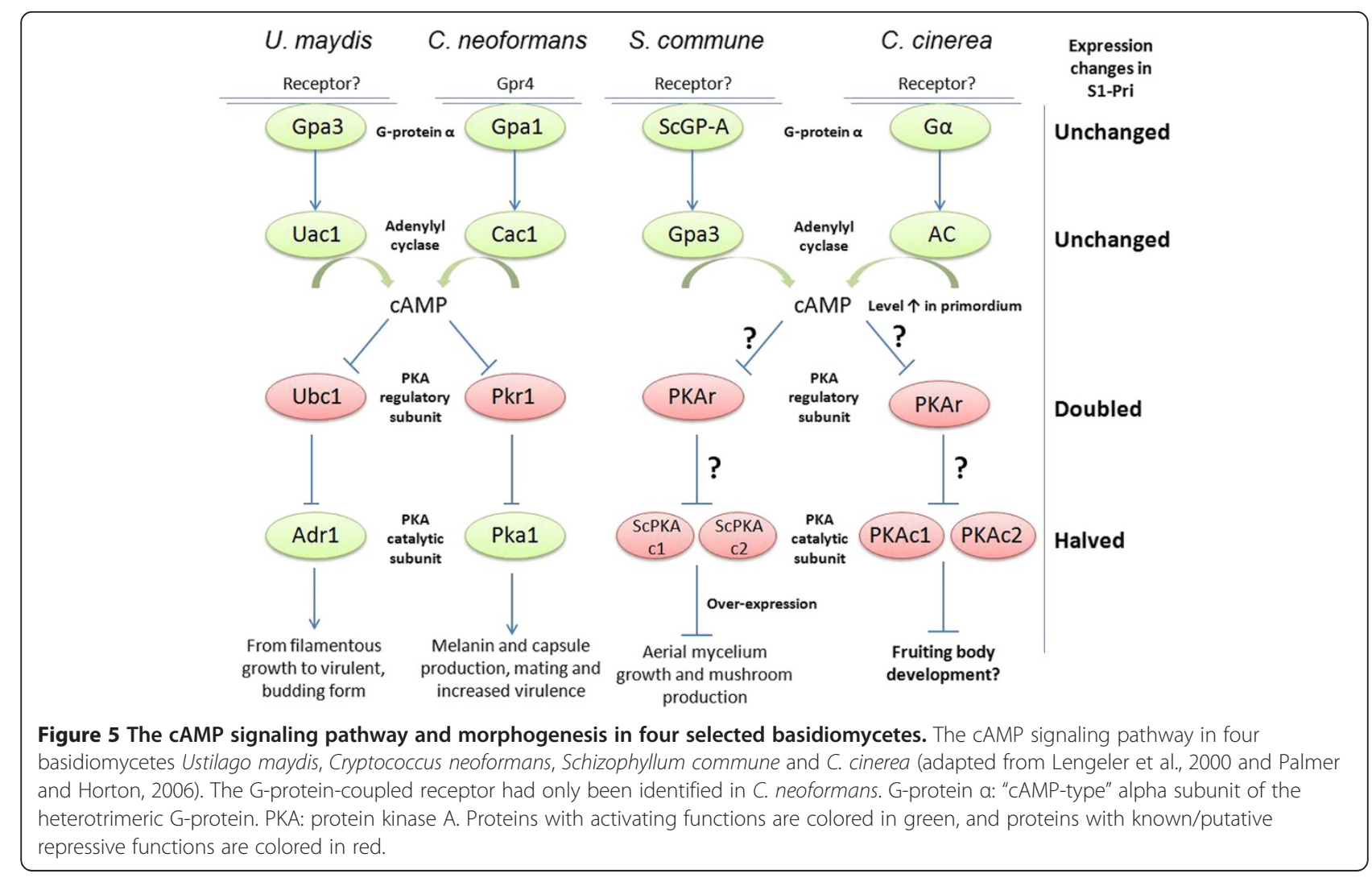


edodes [58]. It was also shown that mutation of the protein kinase regulator Cc.ubc2 (CC1G_00975) gene blocked phosphorylation of a presumptive MAP kinase [59]. Nevertheless, not only was expression of the Cc.ubc2 gene not detected in either developmental stage in our $5^{\prime}$-SAGE data, we also showed low expression levels for the components in the MAP kinase pathway. However, real-time PCR demonstrated that two loci of MAP kinase (CC1G_07620 and CC1G_03633) were up-regulated by 0.4 fold and down-regulated by $70 \%$ in S1-Pri respectively. Consistent with such results, expression of MAP kinase kinase loci (MAPKK) (CC1G_03368 and CC1G_02205) were upregulated by 1.2 -fold and down-regulated by $78 \%$ in S1-Pri respectively. It is unclear whether the two apparent subsets of MAPK/MAPKK combinations function independently, despite the high similarity in the conserved functional domains in these kinases. Accordingly, the budding yeast Ras2 homolog (CC1G_04430), which has been implicated to function as an upstream activator of both the cAMPPKA and MAPK signaling cascades [60,61], was also found to be moderately up-regulated by 0.5 -fold in S1-Pri. This suggests that the MAPK pathway and its activator may still be necessary although not up-regulated, for fruiting body development in C. cinerea.

\section{KEGG pathways analysis revealed an increased cellular metabolism in S1-Pri}

Among the 270 up-regulated genes (38\%) in S1-Pri in which a KEGG ortholog could be identified (Table 3), 62 (23\%) were annotated to be constituents of ribosome and most of the remaining were mapped to metabolic pathways involving oxidative phosphorylation (27), nucleotide metabolism (14), TCA cycle (6), sugar metabolism (7), amino acids metabolism (20) and protein degradation (12) (Additional file 6). This implies a significant higher demand for energy production, DNA synthesis, protein synthesis machinery and turnover during fruiting body development. In contrast, only 56 up-regulated genes (17\%) in Myc were assigned a KEGG ortholog, and almost all of them were mapped to basic cellular metabolism pathways (Additional file 7). Furthermore, these 56 genes were assigned to as many as 69 different pathways and most of which only had one and two mapped components (47 and 19 respectively), thereby implying that few pathways are preferentially up-regulated during mycelial growth. Moreover, a remarkable 20\% of Myc and 45\% of S1-Pri DEGs with KEGG ortholog could not be assigned to a KEGG pathway.

\section{Novel pathways potentially involved in fruiting body development}

Among the up-regulated pathways in S1-Pri, we are particularly interested in novel signaling pathways [62]. Two up-regulated genes in S1-Pri were assigned to the mTOR signaling pathways, and real time PCR confirmed the 5'-SAGE observations for these two DEGs (CC1G_ 10718 \& CC1G_00269). The mTOR signaling pathway is of particular interest as the TOR pathway is wellconserved from animals to fungi [63-65] (Figure 6). TOR (Target of Rapamycin) is a serine/threonine protein kinase controlling a wide range of cellular events in response to different environmental cues such as stimulation by growth factors, changes in nutrient conditions and fluctuation in energy, and is specifically inhibited by FKBP12 protein together with rapamycin [66]. During amino acid (nitrogen) starvation, FKBP12 homologs interfere with TOR and thereby inhibit cell growth. We showed that although TOR (CC1G_00894) and its associated protein Raptor (CC1G_ 00662) had similar expression between Myc and S1-Pri stages, our 5'-SAGE data and real-time PCR recorded a 8.5-fold and 10.6 fold up-regulation of a Rheb homolog (CC1G_00269), a Ras-like small GTPase, which is able to prevent FKBP12 inhibition of TOR in a GTP-dependent manner such that TOR is activated in turn [66,67]. In addition, although the TSC1 homolog cannot be identified, expression of the TSC2 component (CC1G_15321) of the critical TOR negative regulator TSC1-TSC2 (tuberous sclerosis complex) complex remained unchanged. We also demonstrated that two end effectors of the mTOR pathway, translation initiation factor 4B (CC1G_10919) and ribosomal protein small subunit s6e (CC1G_10718), showed a concurrent 1.6-fold up-regulation. We also observed a 2.6-fold up-regulation of a G-protein beta-like homolog (CC1G_06967) that is implicated to play a role in nutrient sensing. Taken together, our observations suggest that this Rheb GTPase homolog and the TOR signaling pathway functions as one of the essential regulators during fruiting body formation.

Furthermore, the protein riboflavin-aldehyde forming (Raf) enzyme was found to be differentially expressed in primordium in both L. edodes [34] and Agaricus bisporus [68] during fruiting body formation. Although our 5'-SAGE data only showed a slight increase in the expression of the raf gene, 4 DEGs (CC1G_13718, 01137, 04209, 11697) in the S1-Pri stage were mapped to the pathway riboflavin metabolism. Genes CC1G_13718 and CC1G_01137 encode the alpha and beta chain of riboflavin synthase, suggesting that an up-regulation of riboflavin synthesis may be a necessary complement to the increase in expression of the Raf enzyme in C. cinerea as well as other fruiting body-forming basidiomycetes.

\section{Protein domain enrichment}

We searched all the annotated ORFs for protein domains using NCBI Conserved Domains [69], NCBI Protein Clusters [70], Pfam [71] and COG [72] databases. A total of 5,868 conserved domains were assigned to 3,751 ORFs at an e-value threshold of $\mathrm{e}<10^{-20}$. The occurrence of 
MTOR SIGNALING PATHWAY

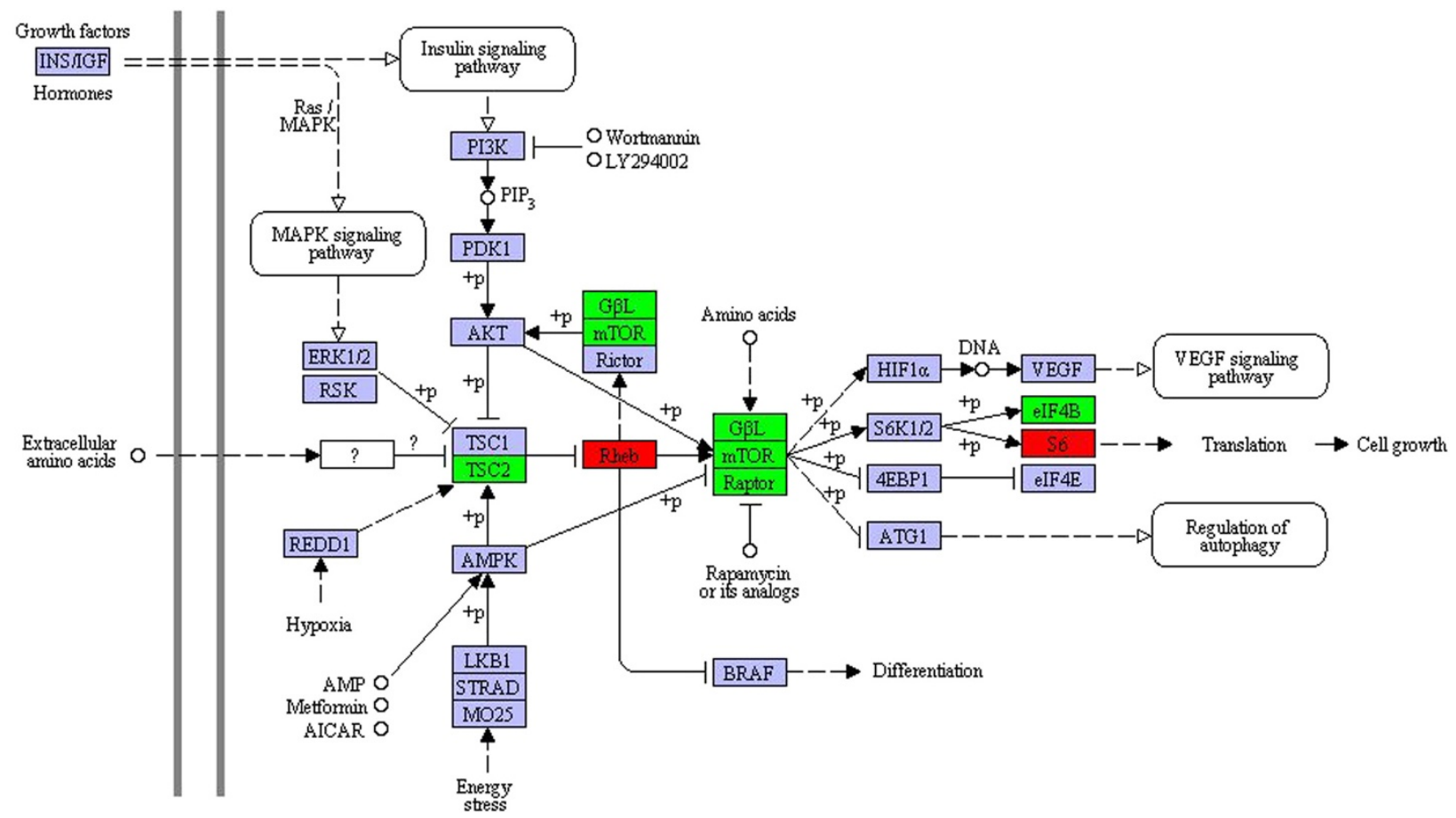

Figure 6 The mTOR signaling pathway in KEGG pathway analysis. The mTOR signaling pathway is among the S1-Pri-up-regulated pathways in KEGG analysis. Rheb and ribosomal protein small subunit s6e (red boxes) were identified through 5'-SAGE as DEGs in the S1-Pri stage. Expression of five other components (green boxes) were verified by real-time PCR.

conserved domains in the Myc and S1-Pri DEGs were compared against all the ORFs. A domain is defined as 'enriched' in the set of DEGs if it has a $p$-value lower than 0.05 in the Fisher's Exact Test. We identified 118 enriched domains in the Myc stage (Additional file 8) and 115 in the S1-Pri stage (Table 3) (Additional file 9). Intriguingly, as many as 93 Myc DEGs-enriched domains are present only once across the genome, and they are all represented in the Myc DEGs but never in the S1-Pri DEGs. This suggests types of protein functions suppressed during fruiting body formation.

We observed an enrichment of PIWI domains [73] in the Myc DEGs. Since this family plays a role in RNA silencing, as found in piwi proteins and a large number of piwirelated nucleic acid-binding proteins, our observations may provide some insights into gene regulation as fruiting occurs [74]. Among these 115 S1-Pri DEGs-enriched domains, 42 belong to the Ras/Rab/Ran families and 11 to the ribosomal protein domains, which are consistent with previous observations of a significant up-regulation of signal transduction and protein synthesis events. Other highly enriched domains in S1-Pri DEGs include 10 enoyl-CoA hydratase, 8 tubulin, 7 ARF (ADP ribosylation factor)/ARF-like domains found in GTP-binding proteins of the Ras superfamily [75], which deserve further investigation to uncover their roles during fruiting body development.

\section{Genes unique to fruiting body-forming basidiomycetes and $\mathrm{C}$. cinerea}

We searched all differentially expressed genes in both Myc and S1-Pri stages against the NCBI BLAST database and specifically against our in-house sequence database which consisted of the protein sequences of Saccharomyces cerevisiae, filamentous fungi (C. neoformans, U. maydis, Aspergillus fumigatus), L. edodes [76], and a number of fruiting body-forming basidiomycetes including L. bicolor [77], Phanerochaete chrysosporium [78], Postia placenta [79], S. commune [80], and two others $P$. ostreatus and $A$. bisporus obtained from the JGI Genome Portal [81]. In order to identify the DEGs that are unique to the fruiting body-forming basidiomycetes, we filtered out the genes in the blast reports that were dissimilar in sequences $\left(\mathrm{e}>10^{-2}\right)$ and used a threshold of $\mathrm{e}<10^{-10}$ to indicate sequence homology among the seven basidiomycetous species. Under these criteria, we identified 22 Myc and 30 S1-Pri DEGs that are uniquely found in at least two fruiting bodyforming basidiomycetes (Additional file 10). We speculate 
that these genes are fundamental and unique to fruiting body development in basidiomycetes despite their roles being unclear. Intriguingly, using the same criterion of $\mathrm{e}<10^{-10}$, we identified 41 Myc and 22 S1-Pri DEGs that were found only in the $C$. cinerea genome (Additional file 11). These genes do not bear any conserved protein domains and were not assigned to any GO terms or KEGG pathways. They may be novel and specific to fruiting body development in C. cinerea.

\section{Conclusions}

We have demonstrated the capability of a combined approach of the $5^{\prime}$-SAGE procedures and high-throughput pyrosequencing to evaluate the transcriptomes of $C$. cinerea at the mycelium and stage 1 primoridum stages respectively. Expression of more than 3,000 genes were assessed, and we showed that one-third of these genes were preferentially expressed in either growth stage, suggesting an overall transcriptomic switch during the transition from mycelium to primordium. Two different sets of structural and functional proteins were found to be uniquely employed in either developmental stage. We demonstrated that sensing the nutrient levels and the environment and response to these changes, in addition to an up-regulation of cellular processes including energy production, DNA/protein synthesis, protein degradation, are crucial for fruiting body development. We also hypothesize an independent regulation of the MAPK and CAMP signaling pathways and an up-regulation of the TOR signaling pathway as necessary requirements. A wealth of candidate genes and anti-sense transcripts potentially related to early fruiting events were also uncovered. The $5^{\prime}$-SAGE data presented in this study serves to advance our understanding of the molecular mechanisms of fruiting body development in $C$. cinerea, which may as well be applicable to the other basidiomycetes that form fruiting bodies.

\section{Methods}

\section{Strains and culturing}

A dikaryotic C. cinerea strain, mated from two wild-type monokaryon strains J6;5-5 and J6;5-4 [82], was used in this study. The two monokaryotic strains were regenerated from single spore isolates of a dikaryotic strain which had been backcrossed with the reference strain Okayama $7 \# 130$, for which its genome sequence is available, for 5 generations. Mycelium (Myc) was grown at $37^{\circ} \mathrm{C}$ in darkness on solid YMG medium and harvested when the mycelium just fully covered the Petri dish (approx. 7 days). Stage 1 primordium (S1-Pri) was grown at $25^{\circ} \mathrm{C}$ under a light/dark regime of $14 / 10 \mathrm{hr}$ $[10,33,82]$ and harvested by picking individual primordia from the base when they were at 2 days prior to karyogamy (height of about $5 \mathrm{~mm}$ ).

\section{Ditag formation}

Total RNA was extracted by $\mathrm{TRI}^{\circledR}$ reagent (Molecular Research Center, Inc) and Poly (A $)^{+}$mRNA was furthered isolated using the PolyATract ${ }^{\circledR}$ mRNA isolation system (Promega). First strand cDNA was synthesized using SuperScript ${ }^{\mathrm{TM}}$ III First-Strand Synthesis System for qRTPCR (Invitrogen). Two different template switching oligos were employed for each developmental stage. Reverse transcription was performed at $42^{\circ} \mathrm{C}$ for 90 minutes. Second strand cDNA was then synthesized by low cycle primer extension using Advantage ${ }^{\circledR} 2$ polymerase (Clontech). Double-stranded cDNA was purified by QIAquick PCR purification kit (Qiagen) and checked by electrophoresis on a $1.5 \%$ agarose gel.

The cDNAs were digested by 10units of $\mathrm{MmeI}$ (New England Biolabs) at $37^{\circ} \mathrm{C}$ for 2 hours. The digested products were extracted by phenol-chloroform and precipitated by ammonium acetate and ethanol at $-20^{\circ} \mathrm{C}$ overnight, then re-suspended at low salt TE $(2.5 \mathrm{mM}$ Tris $\mathrm{HCl}, 0.25 \mathrm{mM}$ EDTA, pH8.0) and electrophoresed on $15 \%$ polyacrylamide gel (Bio-Rad). After electrophoresis, the $\sim 50$ bp bands were excised, disrupted and the DNA contents were eluted and pooled. Following ethanol precipitation with ammonium acetate at $-70^{\circ} \mathrm{C}$ for $4 \mathrm{~h}$, pellets were collected and resuspended in low-salt TE buffer.

The pools of $\mathrm{MmeI}$-digested fragments were ligated by 600units of $\mathrm{T} 4 \mathrm{DNA}$ ligase at $16^{\circ} \mathrm{C}$ overnight to form $100 \mathrm{bp}$ ditags. The ligation mixtures were divided into half and PCR-amplified. The two PCR reactions were then pooled together, extracted by phenol/chloroform and precipitated with ammonium acetate and ethanol. Pellets were collected by centrifugation and resuspended in $15 \mu \mathrm{l}$ ultra-pure water.

\section{High-throughput pyrosequencing}

Prior to pyrosequencing, the identity of the $100 \mathrm{bp}$ ditags were checked by $2 \%$ agarose gel electrophoresis and TA cloning using cloning vector pMD-18 T (Takara Biotechnology). Products of PCR screening with expected size were purified and sequenced for confirmation of the identity of the ditags. The mycelial and primordial ditags were sequenced with a GS20 sequencer in two separate metrics at 454 Life Sciences (Connecticut, U.S.A.).

\section{Tag extraction and genome mapping}

The accuracy of all sequence reads were checked using a Phred-equivalent quality score. Perl scripts were written to remove low-quality sequences, extract valid ditags and subsequently extract individual tags. All tags were mapped to the $C$. cinerea genome sequence obtained from the Broad Institute using Perl scripts [30]. Only tags with a single exact match were retained for further analysis. Singleton tags were also discarded. 


\section{Identification of differentially expressed genes}

The expression level of individual genes was assessed by summing up the occurrence of all the tags mapped to the putative $5^{\prime}$-UTR and dividing this number by the total occurrence of all genome-mapped tags, then multiplying by 100,000, following which they were expressed as tags per hundred thousand in the corresponding stage. Differentially expressed genes (DEGs) between the Myc and S1-Pri stages were defined by a $p$-value of 0.05 in the pairwise Fisher Exact Test.

\section{GO and KEGG analysis}

Protein homologs for all $C$. cinerea predicted gene models were assigned according to the best hit in BLASTX [83] against the NCBI non-redundant protein sequence database $\left(\mathrm{e}<10^{-5}\right)$. Gene Ontology (GO) terms were assigned to protein homologs through BLAST2GO (version 2.4.2) using default parameters [31]. In subsequent $\mathrm{GO}$ term analysis of the differential expression data, corresponding level 2 parent terms were used in "biological process", "molecular function" and "cellular component". KEGG orthologs (KO) and KEGG biological pathways were also assigned through the KEGG Automatic Annotation Server (KAAS) [32] using the following parameters: $\mathrm{BBH}$ (bi-directional best hit method), and all fungal species as the representative gene set.

\section{Oligonucleotide microarray}

The microarray platform, hybridization methods and data analysis have been described [10,33]. More than 13,000 oligonucleotides were designed using ArrayOligoSelector and printed randomly in duplicates on the slides. They were designed to minimize chances of a secondary match, and to be $3^{\prime}$ biased where possible. Myc and S1-Pri RNA samples from biological replicates were isolated from stages mentioned in "Strains and culturing". First-strand cDNA was synthesized and labeled using Superscript Indirect cDNA Labeling System (Invitrogen) with alexa-fluor 635 and 532. Arrays were hybridized in four replicates. Data were captured and analyzed with GenePix 4200A scanner and GenePix Pro software (Molecular Devices). Data for a given oligonucleotide were included if two or more of the four replicates contained data for both probes. Intra-slide normalization and $\log _{2}$ transformation were performed using OLIN (Optimized local intensity-dependent normalization) and data were Z-adjusted to facilitate comparisons among arrays. Significance analysis of microarrays (SAM) was used to determine significant differences in gene expression between samples and the control.

\section{Quantitative real-time RT-PCR}

The reliability of $5^{\prime}$-SAGE data was verified by examining expression of genes showing higher expression in Myc or S1-Pri and similar expression levels. Total RNAs were isolated from Myc and S1-Pri stages mentioned in "Strains and culturing" and were DNase-treated prior to first-strand cDNA synthesis using TaqMan ${ }^{\circledR}$ Reverse Transcription (RT) reagents (Applied Biosystems). RT-PCR primers were designed using the OLIGO ${ }^{\mathrm{TM}}$ software (version 4.0) (National Biosciences). Real-time RT-PCR was performed on the MiniOpticon ${ }^{\text {TM }}$ Real-Time PCR detection system (Bio-Rad) using $\mathrm{iQ}^{\mathrm{TM}} \mathrm{SYBR}^{\circledR}$ Green supermix (Bio-Rad) according to the manufacturer's instructions. Reaction volumes of $20 \mu \mathrm{l}$ containing $2 \mu \mathrm{l}$ of 10X diluted cDNA were used and samples were prepared from biological replicates for each developmental stage and primer pair. Gene CC1G_03085 encoding a clathrin coat assembly protein was selected as the control for normalization. Melting curve analysis was also performed according to the manufacturer's instructions (Additional file 12 and Additional file 13).

\section{Availability of supporting data}

The data sets supporting the results of this article are available in the NCBI Gene Expression Omnibus (GEO) repository under accession GSE40722.

\section{Additional files}

Additional file 1: List of $\mathbf{3 2 7 0}$ genes of which expression is detected in either Myc or S1-Pri stage. Expression level is evaluated by summing up the counts of all tags mapped to the putative $5^{\prime}$-UTR, divided by the total tag counts in the respective stage, and expressed in tags per 100,000

Additional file 2: List of $\mathbf{3 2 4}$ genes differentially expressed in the Myc stage. Expression level is evaluated by summing up the counts of all tags mapped to the putative $5^{\prime}$-UTR, divided by the total tag counts in the Myc stage, and expressed in tags per 100,000. Differential expression is defined by $p<0.05$ in Fisher's exact test.

Additional file 3: List of $\mathbf{7 1 6}$ genes differentially expressed in the S1-Pri stage. Expression level is evaluated by summing up the counts of all tags mapped to the putative $5^{\prime}$-UTR, divided by the total tag counts in the S1-Pri stage, and expressed in tags per 100,000. Differential expression is defined by $\mathrm{p}<0.05$ in Fisher's exact test.

Additional file 4: Microarray data for the $\mathbf{8 6 6 7}$ genes after quality filtering. M_006_z to M_009_z represent four replicate experiments. Values are given as log2 ratio of expression level of Myc divided by that of S1-Pri.

Additional file 5: Gene ontology terms assigned to the differentially expressed genes in both Myc and S1-Pri. We recommend viewing using Gene Ontology Browsing Utility, available at http://gobu.iis.sinica.edu.tw. Run "gobuCmd.bat" in the "gobu" folder after extraction of the downloaded .zip file, wait for the program interface to pop up and load the .txt file into the program.

Additional file 6: KEGG pathway maps assigned to S1-Pri DEGs. KEGG Orthology $(\mathrm{KO})$ id and description can be found in the last two columns of additional file 2 .

Additional file 7: KEGG pathway maps assigned to Myc DEGs. KEGG Orthology $(\mathrm{KO})$ id and description can be found in the last two columns of additional file 1 .

Additional file 8: Protein domains enriched in the Myc DEGs. Additional file 9: Protein domains enriched in the S1-Pri DEGs. 
Additional file 10: Myc and S1-Pri DEGs that are unique to at least two fruiting body-forming basidiomycetes. Ab: Agaricus bisporus; Le: Lentinula edodes; Lb: Laccaria bicolor; Po: Pleurotus ostreatus; Sc: Schizophyllum commune; Pc: Phanerochaete chrysosporium; Pp: Postia placenta.

Additional file 11: Myc and S1-Pri DEGs that are unique to $C$. cinerea.

Additional file 12: Primers used in real-time RT-PCR for crossvalidation of $5^{\prime}$-SAGE and microarray.

Additional file 13: Primers used in real-time RT-PCR for expression validation of additional selected genes.

\section{Abbreviations}

5'-SAGE: 5'-Serial Analysis of Gene Expression; Myc: Mycelium; S1-Pri: Stage primordium; DEG: Differentially expressed gene; TSS: Transcription start site; UTR: Untranslated region; GO: Gene Ontology; KEGG: Kyoto Encyclopedia of Genes and Genomes; RT-PCR: Reverse transcription PCR; HSP: Heat shock protein; CAMP: cyclic adenosine monophosphate; MAPK: Mitogen-activated protein kinase; MAPKK: mitogen-activated protein kinase kinase; PKA: Protein kinase A; TOR: Target of rapamycin.

\section{Competing interests}

The authors declare that they have no competing interests.

\section{Authors' contributions}

Listing those who: Conceived and designed the experiments: HSK, PJP \& MEZ. Performed the experiments: CKC \& SKW. Analyzed sequence data: CHA, CKC and JES. Drafted the manuscript: CKC. Revised the manuscript: HSK, JES, \& PJP. All authors read and approved the final manuscript.

\section{Acknowledgements}

We thank Prof. Fred Dietrich and Zhihong Zhang for providing the detailed $5^{\prime}$-SAGE protocols. We also thank Dr. David Wilmshurst for the revision of the manuscript for grammar and sentence structure. This work was supported by the RGC General Research Fund CUHK466608 from the Research Grants Council of the HKSAR, PR China.

\section{Author details}

${ }^{1}$ Food Research Centre and Food and Nutrition Sciences Programme, School of Life Sciences, Faculty of Science, The Chinese University of Hong Kong, Shatin, S.A.R., Hong Kong. ${ }^{2}$ Department of Biology, University of North Carolina at Chapel Hill, Chapel Hill, North Carolina, USA. ${ }^{3}$ Department of Plant Pathology and Microbiology, University of California-Riverside, Riverside, United States of America. ${ }^{4}$ Department of Biology, Indiana University, Bloomington, Indiana, United States of America.

Received: 10 October 2012 Accepted: 8 March 2013 Published: 20 March 2013

\section{References}

1. Kües U: Life history and development processes in the basidiomycete Coprinus cinereus. Microbiol Mol Biol Res 2000, 604:316-353.

2. Moore D: Graviresponses in fungi. Adv Space Res 1996, 17:73-82.

3. Terashima K, Yuki K, Muraguchi H, Akiyama M, Kamada T: The dst1 gene involved in mushroom photomorphogenesis of Coprinus cinereus encodes a putative photoreceptor for blue light. Genetics 2005, 171:101-108.

4. Kuratani M, Tanaka K, Terashima K, Muraguchi H, Nakazawa T, Nakahori K, Kamada T: The dst2 gene essential for photomorphogenesis of Coprinopsis cinerea encodes a protein with a putative FAD-binding-4 domain. Fungal Genet Biol 2010, 47:152-158.

5. Kamada T, Sano H, Nakazawa T, Nakahori K: Regulation of fruiting body photomorphogenesis in Coprinopsis cinerea. Fungal Genet Biol 2010, 47:917-21.

6. Cooper DNW, Boulianne RP, Charlton S, Farrell EM, Sucher A, Lu BC: Fungal galectins: sequence and specificity of two isolectins from Coprinus cinereus. J Biol Chem 1997, 272:1514-1521.

7. Walser PJ, Kües U, Aebi M, Künzler M: Ligand interactions of the Coprinopsis cinerea galectins. Fungal Genet Biol 2005, 42:293-305.
8. Liu Y, Srivilai P, Loos S, Aebi M, Kües U: An essential gene for fruiting body initiation in the basidiomycete Coprinopsis cinerea is homologous to bacterial cyclopropane fatty acid synthase genes. Genetics 2006, 172:873-884.

9. Mayorga ME, Gold SE: The ubc2 gene of Ustilago maydis encodes a putative novel adaptor protein required for filamentous growth, pheromone response and virulence. Mol Microbiol 2001, 41:1365-1379.

10. Stajich JE, Wilke SK, Ahrén D, Au CH, Birren BW, Borodovsky M, Burns C, Canbäck B, Casselton LA, Cheng CK, Deng J, Dietrich FS, Fargo DC, Farman ML, Gathman AC, Goldberg J, Guigó R, Hoegger PJ, Hooker JB, Huggins A, James TY, Kamada T, Kilaru S, Kodira C, Kües U, Kupfer D, Kwan HS, Lomsadze A, Li W, Lilly WW, et al: Insights into evolution of multicellular fungi from the assembled chromosomes of the mushroom Coprinopsis cinerea (Coprinus cinereus). Proc Natl Acad Sci USA 2010, 107:11889-11894.

11. Velculescu VE, Zhang L, Vogelstein B, Kinzler KW: Serial analysis of gene expression. Science 1995, 270:484-487.

12. Anisimov SV: Serial analysis of gene expression (SAGE): 13 years of application in research. Curr Pharm Biotechnol 2008, 9:338-350.

13. Nielsen $\mathrm{KL}, \mathrm{Høgh} \mathrm{AL}$, Emmersen J: DeepSAGE-digital transcriptomics with high sensitivity, simple experimental protocol and multiplexing of samples. Nucleic Acids Res 2006, 34:e133.

14. Molina C, Zaman-Allah M, Khan F, Fatnassi N, Horres R, Rotter B, Steinhauer D, Amenc L, Drevon JJ, Winter P, Kahl G: The salt-responsive transcriptome of chickpea roots and nodules via deepSuperSAGE. BMC Plant Biol 2011, 11:31.

15. Chum WW, Kwan HS, Au CH, Kwok IS, Fung YW: Cataloging and profiling genes expressed in Lentinula edodes fruiting body by massive CDNA pyrosequencing and LongSAGE. Fungal Genet Biol 2011, 48:359-369.

16. Wei CL, Ng P, Chiu KP, Wong CH, Ang CC, Lipovich L, Liu ET, Ruan Y: $5^{\prime}$ Long serial analysis of gene expression (LongSAGE) and $3^{\prime}$ LongSAGE for transcriptome characterization and genome annotation. Proc Natl Acad Sci USA 2004, 101:11701-11706.

17. Zhang Z, Dietrich FS: Mapping of transcription start site in Saccharomyces cerevisiae using 5/ SAGE. Nucleic Acids Res 2005, 33:2838-2851.

18. Wakaguri H, Yamashita R, Suzuki Y, Sugano S, Nakai K: DBTSS: database of transcription start sites, progress report 2008. Nucleic Acids Res 2008, 36:D97-101.

19. Margulies M, Egholm M, Altman WE, Attiya S, Bader JS, Bemben LA, Berka J, Braverman MS, Chen YJ, Chen Z, Dewell SB, Du L, Fierro JM, Gomes XV, Godwin BC, He W, Helgesen S, Ho CH, Irzyk GP, Jando SC, Alenquer ML, Jarvie TP, Jirage KB, Kim JB, Knight JR, Lanza JR, Leamon JH, Lefkowitz SM, Lei $M$, Li J, et al: Genome sequencing in microfabricated high-density picolitre reactors. Nature 2005, 437:376-380.

20. Hashimoto S, Suzuki Y, Kasai Y, Morohoshi K, Yamada T, Sese J, Morishita S, Sugano S, Matsushima K: $5^{\prime}$-end SAGE for the analysis of transcriptional start sites. Nat Biotech 2004, 22:1146-1149.

21. Keime C, Sémon M, Mouchiroud D, Duret L, Gandrillon O: Unexpected observations after mapping LongSAGE tags to the human genome. BMC Bioinforma 2007, 8:154.

22. Misra S, Crosby MA, Mungall CJ, Matthews BB, Campbell KS, Hradecky P, Huang Y, Kaminker JS, Millburn GH, Prochnik SE, Smith CD, Tupy JL, Whitfied EJ, Bayraktaroglu L, Berman BP, Bettencourt BR, Celniker SE, de Grey AD, Drysdale RA, Harris NL, Richter J, Russo S, Schroeder AJ, Shu SQ Stapleton M, Yamada C, Ashburner M, Gelbart WM, Rubin GM, Lewis SE: Annotation of the Drosophila melanogaster euchromatic genome: a systematic review. Genome Biol 2002, 3. research0083.1-0083.22.

23. Lynch M, Scofield DG, Hong $X$ : The evolution of transcription-initiation sites. Mol Biol Evol 2005, 22:1137-1146.

24. Guida A, Lindstädt C, Maguire SL, Ding C, Higgins DG, Corton NJ, Berriman M, Butler G: Using RNA-seq to determine the transcriptional landscape and the hypoxic response of the pathogenic yeast Candida parapsilosis. BMC Genomics 2011, 12:628.

25. Gowda M, Li H, Alessi J, Chen F, Pratt R, Wang GL: Robust analysis of 5/transcript ends (5/-RATE): a novel technique for transcriptome analysis and genome annotation. Nucleic Acids Res 2006, 34:e126.

26. Alexandrov NN, Troukhan ME, Brover W, Tatarinova T, Flavell RB, Feldmann KA: Features of Arabidopsis genes and genome discovered using fulllength cDNAs. Plant Mol Biol 2006, 60:69-85.

27. Katayama S, Tomaru Y, Kasukawa T, Waki K, Nakanishi M, Nakamura M, Nishida H, Yap CC, Suzuki M, Kawai J, Suzuki H, Carninci P, Hayashizaki Y, Wells C, Frith M, Ravasi T, Pang KC, Hallinan J, Mattick J, Hume DA, Lipovich 
L, Batalov S, Engström PG, Mizuno Y, Faghihi MA, Sandelin A, Chalk AM, Mottagui-Tabar S, Liang Z, Lenhard B, Wahlestedt C, RIKEN Genome Exploration Research Group; Genome Science Group (Genome Network Project Core Group); FANTOM Consortium: Antisense transcription in the mammalian transcriptome. Science 2005, 309:1564-1566.

28. Hung $T$, Wang $Y$, Lin MF, Koegel AK, Kotake $Y$, Grant GD, Horlings HM, Shah N, Umbricht C, Wang P, Wang Y, Kong B, Langerød A, Børresen-Dale AL, Kim SK, van de Vijver M, Sukumar S, Whitfield ML, Kellis M, Xiong Y, Wong DJ, Chang HY: Extensive and coordinated transcription of noncoding RNAs within cell-cycle promoters. Nat Genet 2011, 43:621-629.

29. Wang $X Q$, Crutchley JL, Dostie J: Shaping the genome with Non-coding RNAs. Curr Genomics 2011, 12:307-321.

30. Coprinopsis cinerea Database - Broad Institute. [http://www.broadinstitute. org/annotation/genome/coprinus_cinereus/MultiHome.html].

31. Götz S, García-Gómez JM, Terol J, Williams TD, Nagaraj SH, Nueda MJ, Robles M, Talón M, Dopazo J, Conesa A: High-throughput functional annotation and data mining with the Blast2GO suite. Nucleic Acids Res 2008, 36:3420-3435.

32. Moriya Y, Itoh M, Okuda S, Yoshizawa AC, Kanehisa M: KAAS: an automatic genome annotation and pathway reconstruction server. Nucleic Acids Res 2007, 35:W182-185.

33. Burns C, Stajich JE, Rechtsteiner A, Casselton L, Hanlon SE, Wilke SK, Savytskyy OP, Gathman AC, Lilly WW, Lieb JD, Zolan ME, Pukkila PJ: Analysis of the Basidiomycetes Coprinopsis cinerea reveals conservation of the core meiotic expression program over half a billion years of evolution. PLoS Genet 2010, 6:e1001135.

34. Chum WW, Ng KT, Shih RS, Au CH, Kwan HS: Gene expression studies of the dikaryotic mycelium and primordium of Lentinula edodes by serial analysis of gene expression. Mycol Res 2008, 112:950-964.

35. Ma A, Shan L, Wang N, Zheng L, Chen L, Xie B: Characterization of a Pleurotus ostreatus fruiting body-specific hydrophobin gene, Po.hyd. J Basic Microbiol 2007, 47:317-324.

36. Largeteau ML, Latapy C, Minvielle N, Regnault-Roger C, Savoie JM: Expression of phenol oxidase and heat-shock genes during the development of Agaricus bisporus fruiting bodies, healthy and infected by Lecanicillium fungicola. Appl Microbiol Biotechnol 2010, 85:1499-1507.

37. Raudaskoski M, Kothe E: Basidiomycete mating type genes and pheromone signaling. Eukaryot Cell 2010, 9:847-859.

38. Bertossa RC, Kües U, Aebi M, Künzler M: Promoter analysis of cgl2, a galectin encoding gene transcribed during fruiting body formation in Coprinopsis cinerea (Coprinus cinereus). Fungal Genet Biol 2004, 41:1120-1131.

39. Boulianne RP, Liu Y, Aebi M, Lu BC, Kües U: Fruiting body development in Coprinus cinereus: regulated expression of two galectins secreted by a non-classical pathway. Microbiology 2000, 146:1841-1853.

40. Wälti MA, Walser PJ, Thore S, Grünler A, Bednar M, Künzler M, Aebi M: Structural basis for chitotetraose coordination by CGL3, a novel galectinrelated protein from Coprinopsis cinerea. J Mol Biol 2008, 379:146-159.

41. Uchida M, Mouriño-Pérez RR, Freitag M, Bartnicki-García S, Roberson RW: Microtubule dynamics and the role of molecular motors in Neurospora crassa. Fungal Genet Biol 2008, 45:683-692.

42. Staudt MW, Kruzel EK, Shimizu K, Hull CM: Characterizing the role of the microtubule binding protein Bim1 in Cryptococcus neoformans. Fungal Genet Biol 2010, 47:310-317.

43. Lichius A, Berepiki A, Read ND: Form follows function - the versatile fungal cytoskeleton. Fungal Biol 2011, 115:518-540.

44. Lin WD, Chen YC, Ho JM, Hsiao CD: GOBU: Toward an Integration Interface for Biological Objects. JISE 2006, 22:19-29.

45. Palmer GE, Horton JS: Mushrooms by magic: making connections between signal transduction and fruiting body development in the basidiomycete fungus Schizophyllum commune. FEMS Microbiol Lett 2006 262:1-8.

46. Lengeler KB, Davidson RC, D'souza C, Harashima T, Shen WC, Wang P, Pan $X$, Waugh $M$, Heitman J: Signal transduction cascades regulating fungal development and virulence. Microbiol Mol Biol Rev 2000, 64:746-785.

47. Alspaugh JA, Pukkila-Worley R, Harashima T, Cavallo LM, Funnell D, Cox GM, Perfect JR, Kronstad JW, Heitman J: Adenylyl cyclase functions downstream of the Galpha protein Gpa1 and controls mating and pathogenicity of Cryptococcus neoformans. Eukaryot Cell 2002, 1:75-84.

48. Kues U, Kunzler M, Bottoli APF, Walser PJ, Granado JD, Liu Y, Bertossa RC, Ciardo D, Clergeot P-H, Loos S, Ruprich-Robert G: Mushroom development in higher basidiomycetes; implications for human and animal health. In Fungi in Human and Animal Health. Edited by Kushwaha RKS. India: Scientific Publishers Rks; 2004:431-470.

49. Budhwar R, Lu A, Hirsch JP: Nutrient control of yeast PKA activity involves opposing effects on phosphorylation of the Bcy1 regulatory subunit. Mol Biol Cell 2010, 21:3749-3758.

50. Swamy S, Uno I, Ishikawa T: Regulation of cyclic AMP metabolism by the incompatibility factors in Coprinus cinereus. J Gen Microbiol 1985, 131:3211-3217.

51. Yamagishi K, Kimura T, Suzuki M, Yamaki KJ, Oita S: Identification and overexpression of genes encoding cAMP-dependent protein kinase catalytic subunits in homobasidiomycete Schizophyllum commune. Biosci Biotechnol Biochem 2005, 69:2333-2342.

52. Kaffarnik F, Müller $P$, Leibundgut $M$, Kahmann $R$, Feldbrügge $M: P K A$ and MAPK phosphorylation of Prf1 allows promoter discrimination in Ustilago maydis. EMBO J 2003, 22:5817-5826.

53. Chen C, Dickman MB: CAMP blocks MAPK activation and sclerotial development via Rap-1 in a PKA-independent manner in Sclerotinia sclerotiorum. Mol Microbiol 2005, 55:299-311.

54. Klosterman SJ, Perlin MH, Garcia-Pedrajas M, Covert SF, Gold SE: Genetics of morphogenesis and pathogenic development of Ustilago maydis. Adv Genet 2007, 57:1-47.

55. Abdullah U, Cullen PJ: The tRNA modification complex elongator regulates $\mathrm{Cdc42-dependent} \mathrm{mitogen-activated} \mathrm{protein} \mathrm{kinase} \mathrm{pathway}$ that controls filamentous growth in yeast. Eukaryot Cell 2009, 8:1362-1372.

56. Román E, Arana DM, Nombela C, Alonso-Monge R, Pla J: MAP kinase pathways as regulators of fungal virulence. Trends Microbiol 2007, 15:181-190.

57. Park G, Pan S, Borkovich KA: Mitogen-activated protein kinase cascade required for regulation of development and secondary metabolism in Neurospora crassa. Eukaryot Cell 2008, 7:2113-122

58. Leung GSW, Zhang M, Xie WJ, Kwan HS: Identification by RNA fingerprinting of genes differentially expressed during the development of the basidiomycete Lentinula edodes. Mol Gen Genet 2000, 262:977-990.

59. Nakazawa T, Kondo H, Nakahori K, Kamada T: A mutation in the Cc.ubc2 gene affects clamp cell morphogenesis as well as nuclear migration for diakaryosis in Coprinopsis cinerea. Fungal Genet Biol 2011, 48:519-525.

60. Cherkasova VA, McCully R, Wang Y, Hinnebusch A, Elion EA: A novel functional link between MAP kinase cascades and the Ras/cAMP pathway that regulates survival. Curr Biol 2003, 13:1220-1226.

61. Sengupta N, Vinod PK, Venkatesh KV: Crosstalk between CAMP-PKA and MAP kinase pathways is a key regulatory design necessary to regulate FLO11 expression. Biophys Chem 2007, 125:59-71.

62. Wang $M$, Gu B, Huang J, Jiang $S$, Chen Y, Yin Y, Pan Y, Yu G, Li Y, Wong BH, Liang $Y$, Sun $H$ : Transcriptome and Proteome Exploration to Provide a Resource for the Study of Agrocybe aegerita. PLoS One 2013, 8:e56686.

63. Tokunaga C, Yoshino K, Yonezawa K: mTOR integrates amino acid- and energy-sensing pathways. Biochem Biophys Res Commun 2004, 313:443-446.

64. Sarbassov DD, Ali SM, Sabatini DM: Growing roles for the mTOR pathway. Curr Opin Cell Biol 2005, 17:596-603.

65. Wullschleger $\mathrm{S}$, Loewith $\mathrm{R}$, Hall MN: TOR signaling in growth and metabolism. Cell 2006, 124:471-484.

66. Bai X, Ma D, Liu A, Shen X, Wang QJ, Liu Y, Jiang Y: Rheb activates mTOR by antagonizing its endogenous inhibitor, FKBP38. Science 2007, 318:977-980.

67. Sato T, Nakashima A, Guo L, Tamanoi F: Specific activation of mTORC1 by Rheb G-protein in vitro involves enhanced recruitment of its substrate protein. J Biol Chem 2009, 284:12783-12791.

68. Sreenivasaprasada S, Eastwood DC, Browning N, Lewis SM, Burton KS: Differential expression of a putative riboflavin-aldehyde-forming enzyme (raf) gene during development and post-harvest storage and in different tissue of the sporophore in Agaricus bisporus. Appl Microbiol Biotechnol 2006, 70:470-476.

69. Marchler-Bauer A, Anderson JB, Cherukuri PF, DeWeese-Scott C, Geer LY, Gwadz M, He S, Hurwitz DI, Jackson JD, Ke Z, Lanczycki CJ, Liebert CA, Liu C, Lu F, Marchler GH, Mullokandov M, Shoemaker BA, Simonyan V, Song JS, Thiessen PA, Yamashita RA, Yin JJ, Zhang D, Bryant SH: CDD: a Conserved Domain Database for protein classification. Nucleic Acids Res 2005, 33:D192-196. 
70. Klimke W, Agarwala R, Badretdin A, Chetvernin S, Ciufo S, Fedorov B, Kiryutin B, O'Neill K, Resch W, Resenchuk S, Schafer S, Tolstoy I, Tatusova T: The national center for biotechnology Information's protein clusters database. Nucleic Acids Res 2009, 37:D216-223.

71. Finn RD, Tate J, Mistry J, Coggill PC, Sammut SJ, Hotz HR, Ceric G, Forslund K, Eddy SR, Sonnhammer EL, Bateman A: The Pfam protein families database. Nucleic Acids Res 2008, 36:D281-288.

72. Tatusov RL, Galperin MY, Natale DA, Koonin EV: The COG database: a tool for genome-scale analysis of protein functions and evolution. Nucleic Acids Res 2000, 28:33-36.

73. Cerutti L, Mian N, Bateman A: Domains in gene silencing and cell differentiation proteins: the PAZ domain and redefinition of the Piwi domain. Trends Biochem Sci 2000, 25:481-482.

74. Rivas FV, Tolia NH, Song JJ, Aragon JP, Liu J, Hannon GJ, Joshua-Tor L: Purified Argonaute2 and an siRNA from recombinant human RISC. Nat Struct Mol Biol 2005, 12:340-349.

75. Donaldson JG, Honda A: Localization and function of Arf family GTPases. Biochem Soc Trans 2005, 33:639-642.

76. Au CH: Genome sequence of Shiitake mushroom Lentinula edodes and comparative mushroom genomics with platform construction, $\mathrm{PhD}$ thesis. Hongkong: The Chinese University of Hong Kong, School of Life Sciences; 2011.

77. Martin F, Aerts A, Ahrén D, Brun A, Danchin EG, Duchaussoy F, Gibon J, Kohler A, Lindquist E, Pereda V, Salamov A, Shapiro HJ, Wuyts J, Blaudez D, Buée M, Brokstein P, Canbäck B, Cohen D, Courty PE, Coutinho PM, Delaruelle C, Detter JC, Deveau A, DiFazio S, Duplessis S, Fraissinet-Tachet L, Lucic E, Frey-Klett P, Fourrey C, Feussner I, et al: The genome of Laccaria bicolor provides insights into mycorrhizal symbiosis. Nature 2008, 452:88-92.

78. Martinez D, Larrondo LF, Putnam N, Gelpke MD, Huang K, Chapman J, Helfenbein KG, Ramaiya P, Detter JC, Larimer F, Coutinho PM, Henrissat B, Berka R, Cullen D, Rokhsar D: Genome sequence of the lignocellulose degrading fungus Phanerochaete chrysosporium strain RP78. Nat Biotechnol 2004, 22:695-700.

79. Martinez D, Challacombe J, Morgenstern I, Hibbett D, Schmoll M, Kubicek CP, Ferreira P, Ruiz-Duenas FJ, Martinez AT, Kersten P, Hammel KE, Vanden Wymelenberg A, Gaskell J, Lindquist E, Sabat G, Bondurant SS, Larrondo LF, Canessa P, Vicuna R, Yadav J, Doddapaneni H, Subramanian V, Pisabarro AG, Lavín JL, Oguiza JA, Master E, Henrissat B, Coutinho PM, Harris P, et al: Genome, transcriptome, and secretome analysis of wood decay fungus Postia placenta supports unique mechanisms of lignocellulose conversion. Proc Natl Acad Sci USA 2009, 106:1954-1959.

80. Ohm RA, de Jong JF, Lugones LG, Aerts A, Kothe E, Stajich JE, de Vries RP, Record E, Levasseur A, Baker SE, Bartholomew KA, Coutinho PM, Erdmann S, Fowler TJ, Gathman AC, Lombard V, Henrissat B, Knabe N, Kües U, Lilly WW, Lindquist E, Lucas S, Magnuson JK, Piumi F, Raudaskoski M, Salamov A, Schmutz J, Schwarze FW, vanKuyk PA, Horton JS, Grigoriev IV, Wösten HA: Genome sequence of the model mushroom Schizophyllum commune. Nat Biotechnol 2010, 28:957-963.

81. Grigoriev IV, Nordberg H, Shabalov I, Aerts A, Cantor M, Goodstein D, Kuo A, Minovitsky S, Nikitin R, Ohm RA, Otillar R, Poliakov A, Ratnere I, Riley R,

Smirnova T, Rokhsar D, Dubchak I: The genome portal of the department of energy joint genome institute. Nucleic Acids Res 2012, 40:D26-32.

82. Valentine G, Wallace YJ, Turner FR, Zolan ME: Pathway analysis of radiation-sensitive meiotic mutants of Coprinus cinereus. Mol Gen Genet 1995, 247:169-179.

83. Altschul SF, Gish W, Miller W, Myers EW, Lipman DJ: Basic local alignment search tool. J Mol Biol 1990, 215:403-410.

doi:10.1186/1471-2164-14-195

Cite this article as: Cheng et al: 5 '-Serial Analysis of Gene Expression studies reveal a transcriptomic switch during fruiting body development in Coprinopsis cinerea. BMC Genomics 2013 14:195.

\section{Submit your next manuscript to BioMed Central and take full advantage of:}

- Convenient online submission

- Thorough peer review

- No space constraints or color figure charges

- Immediate publication on acceptance

- Inclusion in PubMed, CAS, Scopus and Google Scholar

- Research which is freely available for redistribution

Submit your manuscript at www.biomedcentral.com/submit 